\title{
Pyramids of Sacrifice? Problems of Federalism in Mandating State Implementation of National Environmental Policy
}

\section{Richard B. Stewart*}

Environmental policy in the United States has reached a difficult impasse. Over the past decade, responsibility for setting environmental policy has increasingly shifted from state and local authorities to the federal government. Reacting to the perceived inability of the states to check or reverse environmental degradation, Congress has enacted comprehensive statutes establishing environmental standards and control strategies. ${ }^{1}$

The federal government, however, is dependent upon state and local authorities to implement these policies because of the nation's size and geographic diversity, the close interrelation between environmental controls and local land use decisions, and federal officials' limited implementation and enforcement resources. The success of federal programs has been gravely compromised by this dependence upon state and local governments, whose generally poor record in controlling environmental deterioration triggered the initial resort to federal legislation, ${ }^{2}$ and whose subsequent performance in the context of federal programs has in many instances remained inadequate."

Some of the difficulties besetting federal environmental programs could be alleviated if federal officials were empowered to require or induce local officials to carry them out. Yet recent court decisionsparticularly that of the Supreme Court in National League of Cities v. Usery $(N L C)^{4}$-have cast considerable doubt on the constitutional

* Professor of Law, Harvard Liniversity.

1. For summaries and analysis of the major environmental laws, see Frder IL ENvironMENTAL LAw (E. Dolgin \& $\Gamma$. Guilbert eds. 1974). Recent examples of comprehensive environmental statutes include: Solid Waste Disposal Act, Pub. L. No. 94-580, 90 Stat. 2795 (1976) (codified at 42 U.S.C.A. \$S 6901-6987 (West 1977)); Toxic Substances Control Act, Pub. L. No. 94-469, 90 Stat. 2003 (1976) (codified at 15 U.S.C.A. $\$ \$ \$ \$$ 2601-2629 (West Supp. 1977)); Safe Drinking Water Act, Pub. L. No. 93-523, 88 Stat. 1660 (1974) (codificd at 42 U.S.C. $\$ \$ 300 \mathrm{f}$ to $300 \mathrm{j}-9$ (Supp. V 1975)).

2. See, e.g., S. Rer. No. 92-414, 92d Cong., 2d Sess. 4-5 (1971), reprinted in [1972] L.S. Code Cong. \& AD. New's 3668, 3671-72 (concern with failure of many states to adopt and adequately enforce water quality standards requires comprehensive amendment of federal water pollution statute).

3. See pp. 1203-04 infra.

4. 426 U.S. 833 (1976). In $N L C$ the Court held that federal minimum wage and maximum hour requirements impermissibly invaded state and local government autonomy in contravention of federalism principles reflected in the Tenth Amendment. 
authority of the federal government to require state implementation of federal programs. This article will consider two strategies for federal conscription of state enforcement resources: enactment of direct mandates and imposition of conditions on federal grants. It will examine the constitutional issues presented, together with underlying questions as to the proper allocation of responsibility for environmental policy between state and federal authorities.

The initial section discusses the difficulties faced by federal officials in effectuating national environmental policies. The article then advances structural explanations for the increasing resort to federal determination of environmental policies, and the corresponding reasons why state and local officials are often unwilling to carry out federal mandates. Succeeding sections discuss the extent of Congress's constitutional authority to require state implementation of federal policies and to impose conditions on federal grants to state and local governments to achieve the same end. The conclusion seeks to answer the crucial question whether the courts should deny or limit congressional power to force unwilling state and local governments to impose heavy sacrifices upon their reluctant citizens for the sake of national goals.

\section{The Burdens of Implementation}

The obstacles to effective implementation of national environmental programs are well illustrated in the current generation of federal air and water pollution control programs. ${ }^{5}$ The failure of prior efforts (heavily dependent on state initiatives) to check air pollution prompted Congress to enact the 1970 Clean Air Amendments, which demand achievement of nationally uniform ambient air quality standards by $1977.0^{\circ}$ However, a great many regions (including our most heavily polluted urban centers) will fail to meet these deadlines for

5. This article will deal primarily with air and water pollution control, fields in which federal policies are highly developed and the difficulties of implementation amply documented. However, the analysis applies generally to other areas of environmental policy, such as Iand use planning or natural resources management, where the obstacles to realization of national policies may be even greater than in the field of pollution control.

6. See 42 U.S.C. $\$ \$ 1857 c-4,-5$ (1970 \& Supp. V 1975).

Because this article was already in galleys when Congtess passed the Clean Air Act Amendments of 1977, Pub. L. No. 95-95, no attempt has been made to indicate modifications of the original sections of the Act whereser the latter sections are cited. The implications of the 1977 amendments are noted below where they are particularly relevant to the analysis. The Clcan Air Act Amendments of 1977 are discussed at 8 ENVIR. REP. (BNA) $567-70$ (1977). 
one or more pollutants despite the statute's provision for "hardship" extensions. $^{7}$ At the same time, the Act's special controls on new major stationary sources of pollution have not been adequately enforced in many areas. ${ }^{8}$ Also disappointing has been the limited success of the Federal Water Pollution Control Act Amendments of 1972 (1972 FWPCA), ${ }^{9}$ enacted to remedy inadequacies of prior programs which had placed greater reliance on pollution control by states. Achievement of the 1977 deadlines for pollution abatement is behind schedule for many sources, particularly in the case of municipal wastewater discharges. ${ }^{10}$ The development of regional programs for waste treatment management and planning is barely underway. ${ }^{11}$ While there are various explanations for these shortcomings, the inability or unwillingness of state officials to enlist themselves in the service of federal environmental programs is a pervasive and important one. ${ }^{12}$ Dependence on unreliable state cooperation could also jeopardize the attainment of new federal initiatives in other areas, such as safe drinking water, ${ }^{13}$ energy conservation, ${ }^{14}$ and coastal zone management. ${ }^{15}$

7. Of 247 national air quality control regions, 146 are in violation of national ambient standards for particulates, 131 of the photochemical oxidant standards, 68 of the carbon monoxide standards, 41 of the sulphur dioxide standards, and 3 of the nitrogen dioxide standards. United States Environmental Protection Agency, Justification of Appropriation Estimates for Committee on Appropriations, Fiscal Year 1978, at A-2 (1977) [hereinafter cited as EPA Estimates]. See generally Council on ENvirosmentil Quility, EnvironMENTAL QUALITY-1976, at 213-37 (1976) [hereinafter cited as 1976 CEQ REPORT].

8. See V. Price, State/Regional Implementation of Pollution Controls 70-76 (1976) (memorandum prepared for Committee on Environmental Decisionmaking, National Academy of Scicnces-National Resource Council).

9. 33 U.S.C. $\$ \$ 1251-1376$ (Supp. V 1975).

10. See 1976 CEQ REPORT, supra note 7, at 15-20; cf. State Water Control Bd. v. Train, 6 Envir. L. RrP. (ELI) 20243 (E.D. Va. Feb. 9, 1976) (relief denied from FWPCA's 1977 deadlines for upgrading sewage treatment works despite claim of insufficient congressional assistance). The EPA has been far more successful in curtailing pollutant discharges from large industrial sources. Wall St. J., Oct. 13, 1976, at 1, col. 1.

11. See Note, Sewers, Clean Water, and Planned Growth: Restructuring the Federal Pollution Abatement Effort, 86 YALE L.J. 733, 752 \& n.90 (1977).

12. See pp. 1201-02 infra.

13. Sce 42 U.S.C. $\$ 300 \mathrm{~g}-2$ (Supp. V 1975) (states primarily responsible for enforcing federal standards for public water systems); $i d$. $\$ 300 \mathrm{~h}-\mathrm{I}$ (states primarily responsible for enforcing federal standards for underground water sources).

14. See 42 U.S.C. $\$ \$ 6322-6323$ (Supp. V 1975) (providing federal assistance to states that develop energy conservation plans prescribing thermal, lighting, and general energy efficiency standards); 42 U.S.C.A. $\$ 6834$ (West 1977) (prohibiting federal grants or loans by federally insured or regulated financial institutions for any new building construction in states that do not have building codes meeting federal encrgy conservation standards); id. $\$ 6327$ (federal grants for "supplemental State energy conservation plans" meeting federal requirements).

15. See 16 U.S.C.A.. $\$ \$ 1454-1455$ (West Supp. 1977) (providing assistance to states for development and administration of coastal zone management programs that meet specific federal requirements). 


\section{A. Obstacles to Implementation of Federal Pollution Control Programs}

The failure of the federal-state partnership to produce timely implementation of congressional air and water pollution control policies has several roots. The statutory objectives and deadlines were in many instances unrealistically ambitious, perhaps intentionally so. Sponsors of the 1970 Clean Air Amendments and the 1972 FWPCA may well have deliberately selected radical goals and unrealistic deadlinessuch as the elimination of all discharges of pollution into navigable waters by $1985^{16}$-in order to dramatize environmental issues, arouse public support for legislation, and persuade polluters that the federal government was committed to substantial control measures. ${ }^{17}$ The sponsors might also have calculated that, even making allowance for probable shortfalls in meeting the specified goals, net progress would be greater than it would be if more moderate and realistic targets were selected. Their ambitious programs met with inevitable resistance from industry and the public, due to the costs of achieving the congressional objectives. ${ }^{18}$ This resistance was exacerbated by the advent in 1973 of an "energy crisis" and a recession, and by Congress's insistence on rigid and costly uniform regulatory measures.

The extent and complexity of pollution problems has also proved far greater than Congress foresaw. ${ }^{19}$ Inadequate administrative re-

16. 33 U.S.C. $\$ 1251(a)(1)$ (Supp. V 1975). The "zero discharge" goal may also be understood as an emphatic expression of the desirability of wastewater recycling. Cf. Final Recommendations to Be Sent lo Congress by National Commission on Water Quality on Amending Federal Pollution Control Act, 6 ENvir. ReP. (BNA) 1890, 1891 (1976) (recommending that Congress redefine zero discharge goal to stress conservation and reuse of resources; also recommending increased federal funding for research in recycling and other waste management techniques).

17. See 2 Environmentil Policy Div., Congressional Reseirch Div., 930 CoNg., 1st Sess., A Legislative History of the Water Pollution Control Act Amendments of 1972, at 1278 (Comm. Print 1973) (quoting remarks of Senator Montoya in the floor debates on 1972 FWPCA):

Your committee has placed before you a tough bill. This body and this Nation would not have it be otherwise. Our legislation contains an important principle of psychology. Men seldom draw the best from themselves unless pressed by circumstances and deadlines. This bill contains deadlines and it imposes rather tough standards on industry, municipalities, and all other sources of pollution.

See also Bonine, The Evolution of "Technology-Forcing" in the Clean Air Act, ENvir. REP. Monograph No. 21 (BN. I) (1975). For a brief critique of this technique, see Stewart, The Development of Adminislrative and Quasi-Constilutional Law in Judicial Review of Enviranmental Decisionmaking: Lessons from the Clean Air Act, 62 IowA L. REv. 713, $764-65(1977)$.

18. See D. Harkison, Who PAYs for ClEIN AIR (1975) (economic waste and regressive income distribution effects attributed to geographically uniform new car emission controls); Roberts \& Stewart, Energy and the Environment, in Setring National Prioritics 411, 440-56 (H. Owen \& C. Schultze eds. 1976).

19. See Tripp, Tensions and Conflicts in Federal Pollution Conlvol and Water Resource Policy, 14 H.skv. J. Lrass. 225, 226 (1977). 
sources and red tape have hampered the Environmental Protection Agency (EPA), the agency with primary responsibility in implementing federal pollution control legislation. For example, attainment of the 1977 water pollution control deadlines has been jeopardized by the EPA's delay in the processing of municipal waste treatment grant applications..$^{20}$ The quality of EPA decisionmaking has often been low, particularly when it has been required to act under tight statutory deadlines for adopting control measures." ${ }^{21}$ As a result, many EPA regulations have been invalidated by the courts," causing significant delays in implementation.

In the field, the inadequacy of resources available to federal agencies for implementation and enforcement is manifest. In the area of water pollution alone, there are over 60,000 major direct dischargers to water bodies, with millions of additional sources causing runoff, ground water contamination, and other indirect forms of pollution. ${ }^{2:}$ Water pollution abatement requires intricate coordination of water supply, waste treatment, and land development programs on a local and regional basis. ${ }^{24}$ The atmosphere is continuously assaulted by some 200,000 stationary sources subject to federal requirements, supplemented by more than 125 million automotive emitters of hydrocarbons, oxides of nitrogen, and carbon monoxide. ${ }^{25}$ The resources available to the EPA for implementation and enforcement-in the neighborhood of 2150 employees with a budget of $\$ 60$ million-are wholly inadequate to monitor and control these numerous and diverse sources of pollution. ${ }^{26}$ The political obstacles to congressional

20. See Colicil on Exvironmestal Quility, Environmental, Quility 71-72 (1975).

21. See 2 Commitree on Environiental Decisionmiking, Nitionil ACademy of Sciences-National Reseirch Covncil, Decisionamaing in the Environmental ProtecTION AGENCY 23-24, 35-39, 40-42, 45-60, 116-20, 127-34 (1977).

22. See Appalachian Power Co. v. Train, 545 F.2d 1351 (4th Cir. 1976); South Terminal Corp. v. EPA, 504 F.2d 646 (1st Cir. 1974); Portland Cement Ass'n v. Ruckelshaus, 486 F.2d 375 (D.C. Cir. 1973), cerl. denied, 417 U.S. 921 (1974).

23. See 1976 CEQ REPORT, supra note 7, at 15, 257, 261; Tripp, supra note 19, at 247$48,251-52$.

24. See Tripp, supra note 19; Comment, Areawide Planning Under the Federal Waler Pollution Control Act Amendments of 1972: Intergovernmental and Land Use Implications, 54 TEX. L. REv. 1047 (1976).

25. See EPA, EPA ENForceMent: A Progress Report 5-6 (1976) (stationary sources); Bureiu of the Cansus, Stitisticil. Absikict of the United Stites-1976, at 597 (1976) (automotive sources).

26. In fiscal year 1976 permanent full-time employees responsible for implementing, testing, monitoring, and enforcing air and water pollution control strategies totaled 2143 , with an allocated budget of $\$ 59,973,000$. EPA Estimates, supra note 7, at A-10, A-42, WQ-10, WQ-48. During the same year the EPA made grants totalling $\$ 137$ million to the states to support air and water pollution control programs. See id. at A-10, WQ-10.

For discussion of the limited resources arailable to the EPA for implementation, and other obstacles to effective implementation of national environmental policies, see 2 ConMittee on Exvirosmextil Degisionmaking, supra note 21, at 36-42. 


\section{Problems of Federalism in National Environmental Policy}

creation and funding of a massive federal inspectorate and police force adequate to the task appear insurmountable. Even if such a force were created, federal environmental goals could not be achieved without the cooperation of state and local authorities with responsibility for water supply, highway location, traffic control, mass transit, land use planning, and other governmental programs related to environmental management. ${ }^{2 \tau}$

The inadequacy of federal resources in comparison to the magnitude of environmental problems inevitably results in federal dependence on state and local authorities. Often federal air and water pollution control statutes give the states initial responsibility (subject to federal review and "back-up" enforcement) for achieving federal objectives. ${ }^{28}$ In other instances, the EPA is authorized to delegate certain of its own implementation and enforcement responsibilities, an option which overburdened federal officials have readily utilized. ${ }^{29}$ Even where no formal delegation has occurred, the EPA in practice relies heavily upon the cooperation of state officials. ${ }^{30}$

Yet the indispensable contribution of the states to achieving federal objectives has been (with a few notable exceptions) seriously inadequate. $^{31}$ The funding normally available to state environmental agencies is gravely deficient, given their responsibilities, and personnel are often few in number and lacking in technical qualifications. ${ }^{32}$ These already weak state agencies are exposed to intensive pressure from politicians, industry, unions, and citizens reacting to the costs (economic and otherwise) of controlling pollution and the possibility of unemployment and curtailment of economic development. ${ }^{33}$ State

27. For example, efforts to improve water quality must be coordinated with water supply and recycling, limits on agricultural and residential development in areas vulnerable to rumoff, and industrial siting. See Tripp, supra note 19, at 225-27, 247-49, $253-57,278-80$.

28. See, e.g., 42 U.S.C. $\$ 1857 c-5$ (1970 \& Supp. V 1975) (under the Clean Air Act states hase authority in first instance to derelop implementation plans to achiere federal ambicnt air quality standards); 33 C.S.C. \$s 1319(a)(1), 1342(b) (Supp. Y' 1975) (states with regulatory programs approved by EPA Administrator have initial responsibility for enforcement of effuent limitations under 1972 FWPCA).

29. For examples of statutory provision for delegation, sec 42 U.S.C.A. $\$ 1857 \mathrm{c}-6(\mathrm{c})$ (WVest Supp. 1977) (Clean Air Act); 33 U.S.C. \$ 1342(b) (Supp. V 1975) (1972 FWPCA). A summary of the states' rolc in implementing water pollution controls may be found in 1976 CEQ Rrvorr, supra note 7 , at $20-23$.

30. See V. Price, supra note 8 , at $3-4$.

31. Sce id. at 5; Robcrts, The Political Economy of Implementalion: The Clean Air ict and Slationary Sources, in Approiches to Con Iroldixg AIr Pollution (N. Friedlander cal.) (forthcoming 1977).

32. These resource limitations have been partly overcome by federal grants to support state programs. Sce note 26 supra.

33. See, e.g., V. Price, supra note 8, at 18, 32-33, 46; Roberts, supra note 31 . 
officials have few strong incentives to assume the administrative and political burdens of carrying out environmental policies dictated by federal agencies. Federal leadership in setting ambitious environmental goals, federal funding of state environmental agencies, and federal enforcement authority have been, at best, only partially successful in stimulating vigorous state implementation of federal measures. At worst, federal policies have been postponed, compromised, or simply ignored.

This record is particularly troubling because national environmental policies will in the future be even more dependent upon state and local measures. In the fields of air and water pollution control, we are reaching the end of "first generation" control strategies which rely primarily on installing "end-of-pipe" cleanup technology upon relatively few large "point sources" of pollution. In the years ahead, effective control of many forms of pollution will require monitoring of numerous sources, an extensive enforcement capability, coordination of pollution control policies with land use planning, and other measures that cannot succeed without the assistance of state and local officials. Reliance on state efforts will also become increasingly important in areas of environmental policy other than pollution control. Reduced use of pesticides and chemical fertilizers will require the cooperation of state agricultural and licensing officials in promoting integrated pest management and other more ecologically benign agricultural practices. Developing federal programs aimed at preservation of wetlands and other coastal resources are heavily dependent upon state and local authorities. Similar dependence seems inevitable in federal programs to conserve energy ${ }^{34}$ and water. ${ }^{35}$ Many state and local officials will try to shun responsibility for implementing federal measures in these fields because such measures will curtail existing patterns of economic development and preempt local decisionmaking.

\section{B. The Unhappy Saga of Federal Transportation Controls}

The dependence of national environmental policies on local cooperation is exemplified by the EPA's largely unsuccessful efforts to secure implementation of federal controls on motor vehicle use. An examination of the disputes which developed will also illuminate

34. See 42 U.S.C. $\$ \$ 6322-6326$ (Supp. V 1975) (federal grants for state energy planning).

35. For example, federal efforts to regulate use of the limited water resources of the Colorado River Basin have been impaired by unilateral, uncoordinated state land-use decisions that have substantially increased the salinity of the river's waters. See The Colorado: Run Red, Run Salty, Run Dry, 9 NAT'L J. 540, $542-45$ (1977). 
the competing values at stake in the constitutional debate over whether such cooperation may be compelled.

As required by the Clean Air Act, the EPA has promulgated federal ambient standards for air pollutants attributable to automobile emissions which must be achieved by $1977 .^{36}$ While the Act imposes federal limitations on emissions from new automobiles, the reductions obtained through such limitations have not been sufficient to achieve federal ambient standards for automotive pollutants in over 25 of the nation's largest and most heavily polluted metropolitan areas, and in many such areas the limitations will not ensure attainment of those standards in the forseeable future. ${ }^{3 i}$ In the latter areas, the federal standards can only be achieved by the retrofitting of control devices on old automobiles (which constitute the bulk of the operational fleet) or restrictions on automobile use through devices such as heavy parking fees, limits on parking in and access to polluted areas, measures to encourage car-pooling and resort to mass transit, and heavy taxation or rationing of gasoline. ${ }^{38}$

Under the Clean Air Act, the states have responsibility to adopt state implementation plans (SIPs) for regions of the state to control pollution sources to the extent necessary to achieve federal ambient standards. ${ }^{39}$ If the EPA judges an SIP to be inadequate, it is required to disapprove the SIP; if the responsible state declines to revise the SIP so as to ensure achievement of federal ambient standards, the EPA is required to promulgate an adequate SIP for that region. ${ }^{40}$ Many states failed or refused to adopt SIPs with automobile emissions controls adequate to meet the federal ambient standards because the necessary restrictions on parking and automobile use were strenuously

36. 42 U.S.C. $\$ 1857 \mathrm{f}-1(\mathrm{a})(\mathrm{l})$, (b)(1)(A) (1970 \& Supp. V 1975); 40 C.F.R. $\$ \S 85.001-$ .1807 (1976).

37. See H.R. REP. No. 94-1175, 94th Cong., 2d Sess. 189-90 (1976).

The limited success of federal emission limitations for new automobiles is in part attributable to the repeated statutory and administratice extension of the original emission limitation deadlines imposed by the 1970 Clean Air .Ict Amendments, see Stewart, supra note 17 , at $734 \mathrm{n} .105$, and by Congress's use of regulatory controls, backed by sanctions that are not credible, in an effort to force technological change, see note 55 infra (citing sources). The Clean Air Act Amendments of 1977 in many cases extended the deadlines imposed in 1970 for achieving compliance with federal ambient standards. Pub. L. No. 95-95 \$\$ 111, 112, 129.

38. See, e.g., District of Columbia v. Train, 521 F.2d 971, 979-80 (D.C. Cir. 1975), vacaled and remanded per curiam sub nom. EPA v. Brown, 97 S. Ct. 1635 (1977) (description of EPA's Transportation Control Plan for Washington, D.C., metropolitan region). See also Chernow, Implementing the Clean Air Act in Los Angeles: The Duly to Achieve the Impossible, \& ECoLoGY L.Q. 537, 562-68 (1975) (listing and describing alternative strategies).

39. See 42 U.S.C. \$ 1857c-5(a)(1), (a)(2), (c)(1) (1970 \& Supp. V 1975).

40. See id. $\$ 1857 \mathrm{c}-5(\mathrm{c})(1)$. 
opposed by downtown merchants, commuters, and others dependent upon automobile use and access. ${ }^{41}$ There was also bitter resistance by developer interests to EPA efforts to secure state adoption of restrictions on new "indirect sources" of pollution, such as shopping centers, large parking facilities, sports complexes and highways, which would attract a heavy concentration of automobiles. As a result, the EPA was required in many instances to devise transportation control plans (TCPs) and indirect source controls for inclusion in state SIPs. ${ }^{42}$

This step was only the beginning of the EPA's troubles. State and local officials refused to enforce many of the agency's unpopular controls. Such draconian measures as the announcement that San Franciscans must cut annual auto mileage by $97 \%{ }^{43}$ were regarded as both incredible and laughable. Lacking the resources itself to impose sweeping restrictions on parking and automobile access in most of the nation's major cities, the EPA issued regulations requiring states either to adopt adequate transportation controls or to implement EPAdrafted controls. The regulations provided that failure by state officials to implement TCPs would itself constitute a violation of the SIP, exposing the state to EPA enforcement orders and civil or criminal penalties. ${ }^{4 *}$ Several states sought judicial review challenging the regulations and denying their liability to criminal or civil sanctions for failure to submit to EPA demands. Three of the four courts of appeals that heard such cases denied, in whole or in part, the enforcement power asserted by the EPA against state officials. ${ }^{45}$ Adverting to grave constitutional problems that would be raised by congressional coercion of state officials to carry out federal programs, two courts construed the statute to avoid constitutional questions and found that Congress had not conferred the disputed enforcement

41. See Stewart, supra note 17 , at 726 \& $n .64$.

42. See id.

43. 38 Fed. Reg. 3124t (1979) (EPA estimate).

44. See 40 C.F.R. $\$ \$ 52.257(\mathrm{c}), .258(\mathrm{f}), .259(\mathrm{f})$ (1976) (transportation controls); $i d$. $\$ \$ 52.242(\mathrm{f}), .243(\mathrm{f}), .244(\mathrm{f})$ (air pollution controls).

45. Maryland v. EPA, 530 F.2d 215 (4th Cir. 1975), vacaled and remanded per curiam sub nom. EPA v. Brown, 97 S. Ct. 1635 (1977); District of Columbia r. Train, 521 F.2d 971 (D.C. Cir. 1975), vacaled and remanded per curiam sub nom. EPA v. Brown, 97 S. Ct. 1635 (1977); Brown v. EPA, 521 F.2d 827 (9th Cir. 1975) vacaled and remanded per curiam, 97 S. Ct. 1635 (1977).

A fourth court found that the EPA possessed statutory authority to compel state implementation of federal requirements, and upheld the constitutionality of that authority. Pennsylvania v. EPA, 500 F.2d 246 (3d Cir. 1974). The court's analysis drew heavily upon the Supreme Court's holding in Maryland v. Wirtz, 392 U.S. 183 (1968), which was overuled by $N L C$. 
powers. ${ }^{46}$ The third court found that enforcement authority had been granted by Congress, but held the authority to be in part unconstitutional. ${ }^{47}$

After granting certiorari to resolve the circuit conflict, the Supreme Court, in EPA v. Brown, remanded the cases because of an apparent concession by the Government that EPA-drafted TCPs should be modified to delete requirements that states adopt implementing regulations. ${ }^{48}$ The Court declined to review the TCPs before the

46. Maryland v. EPA, 530 F.2d 215, 226-27 (4th Cir. 1975), vacated and remanded per curiain stu nom. EPA $v$ Brown, 97 S. Ct. 1635 (1977); Brown v. EP., 521 F.2d 827, 831 (9th Cir. 1975), vacated and remanded per curiam, 97 S. Ct. 1635 (1977).

47. District of Columbia v. Train, 521 F.2d 971 (D.C. Cir. 1975), vacated and remanded per curiam sub nom. EPA v. Brown, 97 S. Ct. 1635 (1977). The court concluded that the Clean Air Act authorized the EPA to require state implementation of EPApromulgated control measures, and held that such authority was constitutional insofar as it required states to remedy pollution from state-owned bus systems or to exclude from state highways vehicles not complying with federal emission controls. Id. at 989-90. However, the court went on to state that requiring states to inspect private automobiles and enforce maintenance and retrofit requirements against such vehicles was an unconstitutional invasion of state sovereignty. Id. at 992-93.

The Second Circuit had occasion to consider, albeit inconclusively, constitutional objections to the EPA's transportation control initiatives in Friends of the Earth v. Carey, 552 F.2d 25 (2d Cir. 1977), which sustained a citizen suit brought pursuant to the Act to require state and city enforcement of transportation controls in New York City. The court found that the suit was plainly authorized by the Act and that there was no constitutional barrier to awarding coercive relief against state officials, both because the transportation control measures in question had been devised by the state rather than the EPA, and because the state had failed to raise constitutional objections to the EPA's approval of those measures in a timely fashion, as assertedly required by $\$ 307$ of the Act and estoppel-like principles.

The former ground for the decision is dubious because the measures in question were not submitted by New York on a wholly voluntary basis; rather, they were in response to the statutory command of the Act and the threat that EPA would devise control measures if the state failed to do so. The "cstoppel" principle is also questionable. It is unclear why a state which macle some efforts to comply with federal requirements should be treated less favorably than states which submitted no control measures at all. The court suggested that New York's submission of a plan, including transportation controls, misled the EPA into relying on state cnforcement and precluded derelopment by the EPA of alternative controls. $I d$. at $34-35$. But these are hardly temable propositions, given the EPA's involvement in negotiating cight of the twelve principal ingredients of the New York plan, the obvious political obstacles to enforcing the New York plan, and the EPA's lack of success in mandating state enforcenent of EPA controls elsewherc.

48. 97 S. Ct. 1635 (1977).

The Solicitor Gencral's petitions from all three courts of appeals decisions challenged them only insofar as they invalidated the regulations reputiring state inspection and maintenance. The Court had also granted V'irginia's petition for review of the bus purchase, bus lanc, and noncomplying vehicle exclusion measures sustaincd in District of Columbia v. Train, 521 F.2d 971 (D.C. Cir. 1975), vacated and remanded per curiam sub nom. EPA v. Brown, 97 S. Cit. 1635 (1977), but the EP.I stbsequently repealed the bus purchase regulations. Id. at 1637 .

The challenged EPA regulations required the recalcitrant state to submit "legally adopted regulations" to implement generally-phrased EPA requirements, such as "inspection of all ... motor rehicles at periodic intervals no more than one year apart by 
EPA had modified them and the validity of the modified regulations had been considered by the courts of appeals. It further suggested that the original controversies might be moot. ${ }^{49}$ As a result of these various court decisions and continued state and local opposition to TCPs, EPA's efforts to control pollution from automobiles in use have been largely frustrated.

If the EPA recasts its regulations and the Supreme Court decides to entertain the matter again, the Court will be faced with difficult questions as to the statute's construction and constitutionality. The Court might well follow those lower courts which found that the Clean Air Act does not grant the EPA the enforcement authority it claims; the statute does not clearly authorize coercive sanctions against state officials. A decision to the contrary, as the subsequent discussion demonstrates, would raise novel and difficult constitutional issues whose fitness for judicial resolution is doubtful. The Court would therefore be justified in insisting on a clear statement from Congress of an intention to intrude upon traditional areas of state

means of a loaded emission test," and also required submission of any "necded statutory proposal." See, e.g., 40 C.F.R. $\$ 52-1095$ (c)(1), (f)(I) (Metropolitan Baltimore Plan).

The Government's brief conceded "the necessity of removing from the regulations all requirements that the States submit legally adopted regulations; the [EPA's] regulations contain no requirement that the State adopt laws." Brief for Petitioner at 20 n.14, EPA v. Brown, $97 \mathrm{~S}$. Ct. $1635(1977)$. The Court interpreted the Government's somewhat ambiguous position to be that "while the challenged transportation plans do not require the enactment of state legislation, they do now contain, and must be modified to eliminate, certain requirements that the Statc promulgate regulations." $97 \mathrm{~S}$. Ct. at 1637 (emphasis in original).

49. 97 S. Ct. at 1637 .

In its effort to avoid decision of a difficult casc, the Court would have been justified in requiring the Government to specify one of two alternative questions for revicw: whether the EPA may impose a general requirement that states reduce automotive emissions sufficiently to meet the ambient standards (leaving -to state legislators and administrators the choice of appropriate measures); or whether the EPA may impose detailed implementing requirements directy on the administrative officials responsible for executing them. Both alternatives raise constitutional questions since they represent. conspicuous federal interference with political self-determination. The second strategyEPA issuance of detailed orders to state officials-would raise the further issue of whether federal commands would confer on such officials executive authority which they lack under state law. Cf. Washington Dep't of Game v. FPC, 207 F.2d 391, 395-96 (9th Cir. 1953), cert. denied, 347 U.S. 936 (1954) (state laws requiring permit before construction of dam would not prevent FPC from issuing license to build dam on nas igable water).

The two strategies may be viewed as differing merely in degree. To be sure, the specificity of an order incorporating precise instructions as to how a state should curb its pollution transccncls that of a directive simply to bring air and water quality up to standard. But given the significant intrusion on state sovereignty implicit in the core demand that onerous federal objectires be met, the degree of detail in the implementing instructions appcars to be an insubstantial subsidiary factor in the constitutional calculus. However, detailed federal requirements may place more explicit responsibility on federal officials for locally unpopular measures, triggering an additional "political siffeguard of federalism" which is relevant to the constitutional calcults. See p. 124 I infra. 
autonomy before it considers the constitutional issues. Such insistence would also ensure that the "political safeguards of federalism," inherent in the geographical basis of congressional representation and local orientation of American politics, operate effectively. ${ }^{50}$

In these circumstances, it is desirable that Congress explicitly consider the question of the EPA's power to mandate state implementation of federal measures under the Clean Air Act. There are three basic alternatives for achieving effective control of automobile emissions within the forseeable future.

First, Congress could explicitly authorize the EPA to compel state and local implementation of measures to reduce emissions from cars in use. This would squarely raise the constitutional issues avoided in EPA v. Brown, and invite an extension of $N L C$, which found that an otherwise valid assertion of congressional power impermissibly compromised state autonomy. However, Congress recently failed to seize this alternative. In the 1977 Clean Air Act Amendments Congress failed to clarify the applicability of the Act's enforcement provisions to states who refuse to implement federally drafted TCP programs. ${ }^{51}$

Second, conditions could be imposed on federal grants to state and local governments, requiring them to implement automobile pollution controls in order to receive continued funding. This alternative was suggested by several lower courts in the TCP decisions, ${ }^{52}$ and was adopted in limited form in the 1977 Clean Air Act Amendments. These amendments authorize cutoffs of Glean Air Act grants and highway and other transportation grants to states that fail to carry out the modified TCP requirements adopted in these same amend-

50. For discussion of the political safeguards of federalism and the implications of such safeguards for statutory construction, see Stewart, supra note 17, at 741, 759-62; Tribe, Intergovermmental Immunilies in Liligation, Taxation, and Regulation: Separalion of Powers Isstes in Controversies About Federalism, 89 H.1Rv. L. Rrv. 682, 695-96 \& nn.71, 73 (1976); Wechsler, The Political Sufeguards of Federalism: The Role of the States in the Composition and Selection of the Nalional Government, 54 Colum. L. Rev. 543, 540 (1951); Note, Municipal Bankruplcy, the Tenth Amendment and the New Federalism, 89 H.1Rv. L. REv. 1871, 1874-78, 1886-87 (1970).

51. Section 111 of the 1977 Clean Air Act Amendments, Puls. L. No. 95-95 \$ 111, introduced several modifications in the enforcement provisions in $\$ 113$ of the Act, 42 U.S.C. \$ 1857c-8 (1970 \& Supp. V 1975), but failed to modify or otherwise clarify whether the existing provisions authorizing the EPA to mandate enforcement by or impose sanctions upon "any person . . . in violation of an applicable [SIP]" applies to states in the TCP context.

52. See Maryland v. EPA, 530 F.2d 215, 228 (4th Civ. 1975), vacaled and remanded per curiam sub nom. EPA $\because$. Brown, $97 \mathrm{~S}$. Ct 1635 (1977) (pointing to "altermative whip of economic pressure and seductive favor"); District of Columbia v. Train, 521 F.2d 971, 99312.26 (1975), vacated and remanded per curiam sub nom. EPA . Brown, 97 S. Ct. 1633 (1977). 
ments. ${ }^{\overline{3} 3}$ However, as will be developed below, ${ }^{54}$ it is unclear whether these threatened sanctions will prove effective, in part because $N L C$ has complicated already serious questions as to the constitutional extent of Congress's conditional spending power.

A third approach appears, at first blush, to offer a means of avoiding constitutional objections altogether. Congress could adopt alternatives to regulatory controls, such as the imposition of emission fees on new and used automobiles, that might prove more efficacious in reducing pollution. ${ }^{55}$ But insofar as such fees are imposed on automobiles in use, state cooperation would still be required in monitoring emissions and excluding from the highways automobiles on which fees had not been paid. Because such fees would be quite unpopular, federal coercion of state officials or conditional spending sanctions would probably also be necessary to implement a fee system. Thus, this alternative will also implicate the constitutional limits of Congress's power to enlist state enforcement of federal programs. Accordingly, the transportation control example demonstrates that the future success of efforts to reduce pollution through controls on automobile use in the United States may turn to a considerable degree on the constitutionality of congressional attempts to compel state implementation of such controls. These same constitutional questions

53. Section 129 of the 1977 Clean Air Act Amendments, Pub. L. No. 95-95 $\$ 129$, adds $\$ 176$ (a) to the Act. Section 176(a) provides that the EPA Administrator shall not makc any grants or approve any projects uncler the Clean Air Act, and that the Secretary of Transportation shall not approve any project or award any grants under 23 U.S.C. (other than for safety, mass transit, or transportation improvement projects related to air quality improvement or maintenance), in any air quality regions that have not attained federal ambient standards and for which the state has failed to submit or carry out TPC measures required for eventual attainment of such standards. The earliest date at which such sanctions could be imposed is July 1,1979 .

In addition, $\$ 176(\mathrm{~b})$ of the Act as amended prohibits the EPA from making any grants under the Clean Air Act in areas of a statc where any SIP requirement is not being implemented by state or local officials.

Section $176(c)$ of the Act as amended contains a nebulous provision prohibiting any federal authority from engaging in, "supporting" in any way, providing financial assistance for, approving or licensing any activity that does not conform to a SIP. This provision not only extends the grant termination sanctions in the previous subsections, but also enlists in the service of clcan air the extensive federal regulatory authority over many activities not directly related to air pollution control. Depending on its construction and enforcement, this provision could have potentially far-rcaching implications.

54. See pp. 1250-62 infra.

55. See Mills \& White, Government Policies Tow'ard Automolive Emissions Control, in Appro.ichrs to Control.tixg . IIR Pollution, supra note 31 (discussing studies). The current regulatory approach, repuiring all new cars to met particular emissions lesels br specificd deadlines, is cconomically wasteful, sce D. H.trkison, supra note 18, at 127-28; has failed to spur derclopment by domestic manufacturers of new automotive technologies at an adequate pace; and has triggered continued postponements of the deadlines set out in the 1970 Clean Air Amendments. See Stewart, supra note 17, at 734 n.105. 
will also have a major bearing on the success of other federal environmental programs which will require state assistance to achieve their objectives.

The theoretical reach of congressional porver does not, of course, by itself determine the extent to which the nation's environmental aspirations will be realized. Congress, however sweeping its constitutional prerogative, will remain wary of control measures likely to be viewed by the public as excessively burdensome. ${ }^{56}$ Environmental measures will never be implemented if their worth and legitimacy are not eventually accepted by a fair proportion of state and local authorities and the citizenry at large. ${ }^{.57}$

Yet one need not hold to an Austinian conception of law to believe that the availability of federal sanctions over state and local officials will have a material impact on the eventual acceptance or rejection of national goals. The availability of sanctions, even if infrequently utilized, alters expectations and actors' assessments of their respective bargaining positions, and enhances the perceived seriousness and moral force of government policy. That Congress in 1970 and 1972 adopted amendments to the federal pollution control acts which gave those acts substantially more effective sanctions ${ }^{58}$ has undoubtedly played a role in industry acceptance of many of the basic features of federal pollution control programs. The relations among legal sanctions, public attitudes, and political practice are undeniably difficult to trace. But recognition of Congress's constitutional power to mandate state implementation is likely to shape to a considerable degree the future success of national aspirations to achieve a more healthy environment.

Against this exhortatory benefit from recognition of broad congressional power must be set the potential for concomitant burdens

56. The 1977 Clean Air Act Amendments contain numerous provisions relaxing preexisting statutory and regulatory controls that had been igorously resisted by industry, state and local political authorities, and the public generally. See Pub. L. No. 95-95 \$107 (authorizing temporary suspension of pollution control requirements during energy emergencies); id. \$ 108 (limiting EPA's authority to require indirect source controls, bridge tolls, reluction of off-street parking, and certain other TCP measures); $i d$. $\$ \$ 111$, 112 (authorizing delayed compliance orders for certain sources of air pollution); id. \$ 117 (permitting use by primary nonferrous smelters of interruptible controls in certain cases); id. $\$ 127$ (modifying requirements designed to prevent significant deterioration of air quality); $i d$. $\$ 129$ (extending deadlines for attainment of ambient air quality standards).

57. The large number of sources subject to environmental controls and the difficulty and expense of monitoring their compliance mean that volumtary compliance by most sources is essential. Such compliance is unlikely unless controls are perceived as necessary and reasonable. See Roberts, supra note 31 .

58. See Clean Air Act $\$ 113,42$ U.S.C. $\$ 1857 c-8$ (1970 \& Supp. V 1975); 1972 FWPCA $\S 309,33$ U.S.C. $\$ 1319$ (Supp. V 1975). 
upon states and localities. For the transportation control story also illustrates the conflict between local autonomy and national objectives. Implementation of federal transportation controls would entail serious economic and social costs in many areas. Most San Franciscans would strongly prefer continued personal mobility to elimination of smog. Requiring local and state officials to implement federal controls represents a serious interference with local political self-determination. Yet protection of the health of the young, the aged, and the infirm is also a powerful value. The issue of federal constitutional authority to compel state and local implementation of federal requirements is ultimately grounded in a contest of moral claims. It is to these claims and their constitutional significance that the remainder of the article is addressed.

\section{The Dialectical Logic of Federalism}

As a nation, we have traditionally favored noncentralized decisions regarding the use and development of the physical environment. ${ }^{50}$ This presumption serves utilitarian values because decisionmaking by state and local governments can better reflect geographical variations in preferences for collective goods like environmental quality and similar variations in the costs of providing such goods. Noncentralized decisions also facilitate experimentation with differing governmental policies, ${ }^{60}$ and enhance individuals' capacities to satisfy their different tastes in conditions of work and residence by fostering environmental diversity. ${ }^{61}$

Important nonutilitarian values are also served by noncentralized decisionmaking. It encourages self-determination by fragmenting governmental power into local units of a scale conducive to active participation in or vicarious identification with the processes of public choice. ${ }^{62}$ This stimulus to individual and collective education and

59. The federal government has played a decisive role in land use and natural resource development and allocation through its ownership of one-third of the nation's land and its control over interstate and navigable waters. But this role has often been discharged through decentralized decisionmaking within federal administrative agencies. See, e.g., 2 Mineril accessibility on Federal Lands V'I-5, -18 (Harbridge House, Inc. Sept. 1975 Draft) (lack of systematic federal policy for land management).

60. This, of course, was the import of Justice Brandeis's view of the states as little "laboratories." Sce Friendly, Federalism: A Foreword, 86 YALE L.J. 1019, 1034 (1977) (quoting Brandeis).

61. For a spirited defense of such diversity, and a discussion of strategies for preserving it, sce J. Dales, Pollution, Property \& Prices 88-92 (1968).

62. Elazar, The New Federalism: Can The States Be Trusted?, 35 Public Interest, Spring 1974, at 89, 102 (quoting Ignazio Silone):

The first test to be applied in judging an alleged democracy is the degree of selfgoverning attained by its local institutions. If . . the province is governed by the 
self-development is enriched by the wide range of social, cultural and physical environments which noncentralized decisionmaking encourages. As the author has argued at greater length elservhere, ${ }^{63}$ the moral virtues of diversity have special force in the realm of environmental policy, for the condition of the natural environment and the corresponding nature and extent of commercial and industrial development profoundly shape patterns of life and perception.

In our nation, the factors favoring noncentralized decisionmaking have been powerfully reinforced by geography, history, and the structure of our politics. ${ }^{g 4}$ Nonetheless, the presumption in favor of decentralization has in recent years been repeatedly overridden by congressional legislation imposing federal standards and federal measures to control environmental degradation. This section outlines the rationales for increased resort to federal legislation and examines the countervailing reasons for state reluctance to implement federal environmental policies. Such an analysis is an essential first step in understanding the competing claims of national supremacy and local autonomy that underlie the constitutional issues of Congress's power to mandate state implementation of federal policies.

\section{A. The Rationales for Centralization}

Four structural factors hinder governmental provision of high environmental quality on a noncentralized basis and help to explain why resort to federal legislation is a necessary or appropriate complement to rising public concern with environmental quality.

\section{The Tragedy of the Commons and National Economies of Scale}

The Tragedy of the Commons arises in noncentralized decisionmaking under conditions in which the rational but independent pursuit by each decisionmaker of its own self-interest leads to results that leave all decisionmakers worse off than they would have been had they been able to agree collectively on a different set of policies. ${ }^{65}$ States and local communities whose citizens desire environmental quality are also concerned with employment and economic growth.

representative of the central government, there can be no true and complete democracy. Only local gorernment can accustom men to responsibility and independence, and enable them to take part in the wider life of the state.

63. See Stewart, supra note 17 , at $750-54$.

64. See note 50 supra (citing sources).

65. The classic account is Hardin, The Tragedy of the Commons, 162 Sciesce 1243 (1968). 
Given the mobility of industry and commerce, any individual state or community may rationally decline unilaterally to adopt high environmental standards that entail substantial costs for industry and obstacles to economic development for fear that the resulting environmental gains will be more than offset by movement of capital to other areas with lower standards. ${ }^{66}$ If each locality reasons in the same way, all will adopt lower standards of environmental quality than they would prefer if there were some binding mechanism that enabled them simultaneously to enact higher standards, thus eliminating the threatened loss of industry or development. The costs and uncertainties of bargaining among many state or local government units render such a compact improbable. If more rigorous environmental standards were imposed nationwide by the federal government, the transaction cost impediments to common agreement would be much less and all localities might well be better off.

The characteristic insistence in federal environmental legislation upon geographically uniform standards and controls strongly suggests that escape from the Tragedy of the Commons by reduction of transactions costs has been an important reason for such legislation. ${ }^{67}$ The statutory structure of federal environmental programs also reflects other economies of scale that help explain centralizing tendencies. Collection of data and analysis of environmental problems, standard setting, and (in some instances) selection of control measures involve recurring, technically complex issues; such steps can often be taken far more cheaply once on the national level than repeatedly at the state and local level. ${ }^{68}$

66. Under perfect market conditions, displacement of industry or economic development might not occur, because the costs of environmental controls would tend to be offset by lower wage rates reflecting more pleasant working and living conditions. Howeser, in actual practice, this compensating adjustment often will not occur because labor and capital are imperfectly mobile, governmental and union policies inhibit wage rate adjustments, and individuals may be ignorant of some of the benefits of environmental quality, such as lessened health risks.

67. See, e.g., Clean Air Act $\$ 109$, 42 U.S.C. $\$ 1857 c-4$ (1970) (nationally uniform ambient air quality standards); id. $\$ 111,42$ U.S.C. $\$ 1857 c-6$ (1970 \& Supp. V 1975) (nationally uniform cmission limitations for new stationary sources); 1972 FWPPCA $\$ 301,33$ U.S.C. $\$ 1311$ (Supp. V 1975) (nationally uniform effluent limitations); $i d . \$ 306,33$ U.S.C. $\$ 1316$ (Supp. $r$ 1975) (nationally uniform effluent limitations for new sources). Nationally uniform ambient standards set a floor under the operation of Gresham's Law with respect to state-set standards. Nationally uniform emission limitations for existing sources reduce the competitive advantage that firms in less developed areas might otherwise enjoy. Nationally uniform cmission limitations for new sources lessen the capacity of such areas to attract new industry while still complying with ambient standards.

68. See, e.g., Clean Air Act $\$ 108,42$ U.S.C. \$ $1857 \mathrm{c}-3$ (1970 \& Supp. V 1975) (federal goternment to publish information on control techniques and on health effects of pollutants); $i d . \$ 110,42$ U.S.C. $\$ 1857 \mathrm{c}-6$ (1970 \& Supp. $V 1975$ ) (federal government to 


\section{Disparities in Effective Representation}

Much of the politics of pollution control involves conflict between environmental groups and industrial and union interests. ${ }^{69}$ There are persuasive grounds for believing that, on the whole, environmental groups have a comparatively greater impact on policy decisions at the national level, even disregarding "commons" factors that make state and local governments particularly vulnerable to industry and union pressures. It is therefore not surprising that environmental groups should favor determination of environmental policies by the federal government, and that increased public support for environmental protection should translate into increased legislation and regulation at the federal level.

Industrial firms, developers, unions and others with incentives to avoid environmental controls are typically well-organized economic units with a large stake in particular decisions. The countervailing interest in environmental quality is shared by individuals whose personal stake is small and who face formidable transaction costs in organizing for concerted action..$^{70}$ These factors tend to produce more effective and informed representation before legislative and administrative decisionmakers of interests favoring economic development as opposed to those favoring environmental quality. ${ }^{71}$ The technical complexity of environmental issues exacerbates this disparity by placing a premium on access to scarce and expensive scientific, economic, and other technical information and analytical skill.

The comparative disadvantage of environmental groups will often be reduced, however, if policy decisions are made at the national level. In order to have effective influence with respect to state and local decisions, environmental interests would be required to organize on a multiple basis, incurring overwhelming transaction costs. Given such barriers, environmental interests can exert far more leverage by organizing into one or a few units at the national level.

Centralized decisionmaking may imply similar scale economies for

establish nationally uniform new source emission limitations reflecting the degree of emission limitation achievable through "application of the best system of emission reduction which (taking into account the cost of achicving such reduction) the Administrator determines has been adequately demonstrated").

69. See generally J. Davies \& B. Davies, The Politics of Pollution (2d ed. 1976).

70. For cliscussion of the "free-rider" and other "transaction cost" obstacles to effective organization by unorganized individuals with individually small but similar stakes in governmental decisions, sec M. Orson, The Logic of Collective Action (1965).

71. For general analysis of the imbalance in representation between business firms, unions, and other organized cconomic interests on the one hand, and loosely organized proponents of widely shared "public" interests on the other, see Stewart, The Reformation of American Administrative Law, 88 Hakv. L. Rvv. 1669, 1681-87, 1713-15 (1975). 
industrial firms, but these are likely to be of lesser magnitude-particularly if such firms are already national in scope. Moreover, effective representation may be less a function of comparative resources than of attainment of a critical mass of skills, resources, and experience. Industry and development interests can probably deploy these requisites regardless of whether decision is local or national. But a national forum for decision may greatly lessen the barriers to environmental interests' achievement of organizational critical mass, sharply reducing the disparity in effective representation.

In addition to reducing aggregate costs and facilitating achievement of critical mass, environmental advocacy at the national level also affords scale economies in fundraising. Donors may want national coverage in environmental advocacy, or donors in one region (e.g., New York City) may be primarily interested in environmental problems in some other region (e.g., Alaska). These factors, together with the significant start-up costs for effective fundraising, mean that a few national organizations may be able to raise more total resources than numerous local ones. ${ }^{22}$

Finally, environmental groups may enjoy comparatively greater influence at the national level because of the nature and outlook of national decisionmakers. Environmental groups are likely to find more powerful bureaucratic allies in Washington. Both the scale economies of national decisionmaking and fiscal "commons" problems at the state level ${ }^{73}$ result in larger, better-funded, and betterstaffed health and environmental protection agencies at the federal level. ${ }^{74}$ Elected politicians serving in Washington may be somewhat

72. Most of the significant environmental litigation over the past five years has been undertaken by national environmental organizations. Despite the prospect of attorney fee awards for citizen enforcement of pollution controls, see, e.g., 42 U.S.C. $\$ 1857 \mathrm{~h}-2$ (d) (1970), Iocal groups have been inhibited by their limited cxpertisc and lack of "start-up" funds.

For a discussion of the dominant position of nationally oriented organizations in public interest law generally, see Council for Public Interest L.iw, B ilancing the Scales of Justice: Finiscing Public Interest L.iw in America 86-90, 233-34 (1976). In summarizing the achievements of public interest lawyers in the environmental protection field, the Council made reference exclusively to the efforts of large national cnvironmental organizations. $I d$. at $180-85$.

73. A fiscal "commons" problem arises because each state acting independently fears that unilaterally raising taxes will displace inclustry and wealthy taxpayers to other states, even though all states might be better off if they could all agree to raise taxes together. Federal grants-in-aid to the states, funded by nationally applicable federal taxes, serve to alleviate the fiscal commons problem in much the same way that federal environmental legislation responds to environmental commons problems.

74. Environmental groups will also encounter larger and better-funded bureaucratic "enemies" at the federal level, such as the Agriculture and Commerce Departments. But here again, obtaining a critical mass of bureaucratic support may be more significant than the comparative balance of resources among "friends" and "enemics." 
less sensitive to local concerns regarding the costs of environmental protection; in addition, they are subjected to greater cultural and media encouragement to take a "long-run" or "national" perspective favoring environmental concerns.

Centralized decisionmaking does not invariably work to the comparative advantage of environmental groups. For example, intense local environmental concerns may be able to generate a critical mass for effective representation at the local level; if the ultimate decision is made in Washington, the costs of effective representation will rise and the local commitment to influence that decision may wane. Industry may seek preemptive uniform national standards or controls to escape more restrictive state controls. ${ }^{i s}$ But the factors favoring (from the environmental advocate's view) national decisionmaking seem to predominate. This conclusion is supported by the fact that the most effective champions of environmental interests have been national organizations that concentrate on influencing policy at the federal level.

\section{Spillovers}

Even if the "commons" problem were eliminated, decentralized environmental decisionmaking would remain flawed because spillover impacts of decisions in one jurisdiction on well-being in other jurisdictions generate conflicts and welfare losses not easily remedied under a decentralized regime.

The most obvious form of spillover is physical pollution. Prevailing winds or river flows may transport pollution generated in one state to another and visit damage there. These spillovers are in many instances pervasive and far-reaching. For example, a significant percentage of sulfate pollution in the eastern states is attributable to emissions originating hundreds of miles westrvard. ${ }^{76}$ Spillovers can also be psychic and economic. Environmental degradation in pristine areas often imposes substantial welfare losses on individuals in other states who value the option of visiting such areas or who take ideological satisfaction in their preservation. ${ }^{77}$ A state that encourages eco-

75. Sec Curric, Molor I'chicle Air Pollution: Stale Authorily and Federal Pre-Emplion, G8 MIICH. I. Rev. 1083, 1085 (1970).

70. See Altshuller, Regional Transport and Transformation of Sulfur Dioxide to Sulfates in the U.S., $26 \mathrm{~J}$. AIR Polltrion 318 (1976); cf. Likens \& Bormann, Acid Rain: A Serious Regional Environmenlal Problem, 184 Science 1176, 1177 (1974) (discussing "the long-range dispersion" of sulfate pollutants in the United States and Europe).

77. Because states with high environmental quality arc precluded from taxing the benefits of such "long-distance" satisfactions and are also unable to recoup fully the gains of those who visit the state to enjoy its environmental amenities, the resulting 
nomic development at the expense of environmental quality may inflict economic loss (in the form of industrial migration or decreased economic growth) on other states that prefer a higher level of environmental quality. ${ }^{78}$

Bargaining among states to minimize the losses occasioned by such spillovers is costly (particularly given the complexity and wide dispersal of many forms of environmental degradation), and may do little to improve the lot of states in a weak position (such as those in a downwind or downstream location). These states are likely to favor federal intervention to eliminate the more damaging forms of spillover. If spillover losses are sufficiently significant and multidirectional then all states may gain (to a greater or lesser degree) from centralized determination of environmental policies. Predictably, therefore, the need to deal with spillover problems and interstate conflicts was advanced as a justification for federal legislation concerning air and water pollution. ${ }^{79}$

external economies will create a market imperfection that will lead the state to adopt a lower level of environmental quality than would be desirable from the viewpoint of society as a wholc. See Stewart, supra note 17 , at 747 .

Whether interstate ideological impacts from local activity constitute "commerce" and therefore afford a basis for congressional regulation of the local activity is a question that has apparently nerer been judicially considered. Given the broad sweep of the traditional commerce power with respect to material goods and services, see pp. 1222.23 infra, and the authority of Congress to wield that power for moral or idcological ends, see note 132 infra, recognition of "ideological spillovers" as commerce would probably have little practical importance. Nonetheless, a congressional power to regulate a person's activity because it is distasteful to others (an "external preference") might be opposed as constituting a potential threat to individual self-development and diversity, and inconsistent with the premises of a liberal society, in which government limits its concerns to the allocation of material goods and advantages. Sce R. Dworkin, TAking Riguts SeriousLy 276-77 (1977) (rejecting "external preferences" as a valid basis for governmental decision). For discussion of the related question whether an ideological interest in a governmental decision should confer standing to secure judicial review of that decision, see Stewart, supra note 71, at 1737-39.

78. It is also possible that a state seeking unusually high levels of environmental quality could cause economic injury to neighboring states whose economics were dependent on its neighbor's economy. See J. KRIER, Environmental Law AND PolicY 339 (1971).

79. See Water Pollution Control Act of 1948, ch. 758, $\$ 2$ (d), 62 Stat. 1155 (federal remedy when discharge in one state endangers the health or welfare of persons in another state). The current Clean Air Act $\$ 110(\mathrm{a})(2)(\mathrm{E}), 42$ U.S.C. $\$ 1857 \mathrm{c}-5(\mathrm{a})(2)(\mathrm{E})$ (1970), requires that state implementation plans contain

adequate provisions for intergovernmental cooperation, including measures necessary to insure that emissions of air pollutants from sources located in any air quality control region will not interfere with the attainment or maintenance of [federal standards] in any portion of such region outside of such State or in any other air quality control region.

The federal remedies for interstate spillovers in earlier legislation were invoked only infrequently because the procedures involved were cumbersome and time-consuming. However, the provisions in $\$ 110(a)(2)(E)$ will become increasingly important as states achieve compliance with federal standards and maintenance of those standards (or of federal nondegradation requirements) is threatened by emanations from other states. 


\section{Moral Ideals and the Politics of Sacrifice}

The groundswell of public concern with environmental quality that arose in the late $1960 \mathrm{~s}$ had undeniable aspects of a moral crusade with powerful emotional, even religious, undercurrents. ${ }^{80}$ This development cannot be fully explained by utilitarian models that explain individual behavior in terms of calculated preference satisfaction. On the contrary, it partially reflects the sacrifice of preferencesatisfaction in order to fulfill duties to others, or to transform existing preference structures in the direction of lessened dependence upon consumption of material goods and greater harmony with the natural environment. For example, the Clean Air Act assumes an obligation to protect the health of susceptible individuals, such as children or those already suffering from disease, through geographically uniform standards that ensure every individual a minimum healthy environment even though such uniformity is economically inefficient. The preservation of pristine areas may be understood in part as reflecting a special obligation to future generations (despite the fact that they may, in economic terms, be wealthier than we) to prevent the potentially irreversible loss of important categories of human experience. ${ }^{31}$ These measures to preserve natural environments, together with programs to protect endangered species, could also be viewed as an assumption of duties to nature. ${ }^{82}$ Alternatively, they could be understood as a deliberate renunciation of maximum economic progress in order to affirm a different view of the ends of human life to which the society should aspire.

National mechanisms for determining environmental policies facilitate, to a greater degree than their state and local counterparts, the achievement of commitments entailing material sacrifice; the moral content of rising environmental concern thus helps explain the increasing resort to centralized decision. Communities no less than individuals may be far more willing to undertake sacrifices for a common ideal if there are effective assurances that others are making. sacrifices too. ${ }^{\mathrm{s3}}$ National policies can provide such assurances and

80. Sec Ingram, The Polilical Ralionality of Innovalion: The Clean Air Amendments of 1970, in Approiches to Controlling Air Pollution, supra note 31.

81. See Stewart, supra note 17 , at 753 .

82. For discussions of duties to nature in the context of environmental policy, sce Stone, Should Trees Have Standing?-Toward Legal Rights for Nalural Objects, 45 S. C.at. L. Rev. 450 (1972); Tribe, Ways Not To Think About Plastic Trees: New Foundations for Environmental Law, 83 YALE L.J. 1315 (1974).

83. Such assurances may be especially important where sacrifices are imposed directly through government regulation, such as limitations on automobile use, rather than in- 
also facilitate appeals to sublimate parochial interests in an embracing national crusade. ${ }^{s t}$ It is accordingly not surprising that federal pollution control legislation in the early 1970s was conceived and advertised as a national war against degradation and disease. ${ }^{s 5}$

Centralization also makes less apparent the sacrifices involved in public expenditures to promote environmental quality. The relation between one's tax payment into the large and complex federal fisc and any particular federal expenditure is obscure; the correlation between a state or local bond issue for sewage treatment facilities and personal financial sacrifice is more direct and immediate. The ambitious municipal waste treatment programs adopted in federal legislation $^{86}$ would probably have been rejected in many states and localities.

As noted above, the federal health and environmental protection bureaucracies are generally larger and more professional than their state and local counterparts. ${ }^{\text {s7 }}$ Once a substantial program of environmental protection is launched, these federal bureaucracies' very size, professional orientation, and remoteness also makes them comparatively less sensitive to public discontent when the economic and social costs of such programs become apparent, particularly if these costs fall disproportionately on a few regions. ${ }^{8 s}$ For analogous reasons, public protests, especially if localized, will have less impact on federal judges and legislators than on their state and local counterparts.

Thus a variety of "ratchet" factors make it less likely that federal (as opposed to state or local) environmental programs initially undertaken in part out of moral concern will be abandoned or compro-

directly through higher market prices. Joint sacrifice can be viewed as a variant of the commons problem resolvable through national mechanisms that reduce the costs of reaching agreements and provide incentives for adhering to those agreements.

84. Another reason why federal leadership may facilitate sacrifice is that federal power can be wielded to require sacrifices for the benefit of the nation as a whole by a relatively few states that would not voluntarily undertake such sacrifices. Fecleral nondegradation policies mandated by the federal judiciary can be viewed as cases in point. See Stewart, supra note 17 , at $744-45$ \& 1 .159. On the other hand, this contravention of local, direct mechanisms of political accountability in the imposition of uncqual sacrifices is, of course, a prime ground for objection to federal dictation of local environmental policies. See pp. 1221-22, 1255 infra.

85. See Ingram, supra notc 80 .

86. See 33 U.S.C. $\$ \$ 1281-1287$, 1311(b)(1)(B), (b)(2)(B) (Supp. V 1975) (grants for construction).

87. See V. Price, supra note 8, at 21, 82. Economics of scale, avoidance by the federal goternment of "fiscal commons" problems that plague the states, and the comparatively more effective representation of environmental interests at the national level would all help to account for larger and more professional health and environmental bureaucracies at the federal level.

88. See 2 Committee on Environmental Decisionmaning, supra note 21 , at 36-37. 
mised because of the sacrifices entailed. Under centralized decisionmaking these sacrifices may be less visible (because of fiscal mechanisms) or more palatable (because widely shared). Or the sacrifices may be discounted because federal officials are simply less sensitive to short-term swings in public attitudes. These features of national decisionmaking would be welcomed by those who embrace a genuine moral commitment to environmental protection but fear their inability to maintain that commitment in the face of subsequent privations. Delegation of environmental programs to the federal government can accordingly be viewed as a self-binding mechanism-an insurance policy against akrasia. The emphasis in federal programs on wilderness and species preservation, on uniform health-based pollution control standards, and even the extravagant zero-discharge goal of the 1972 FWPCA all reflect the nonutilitarian moral and sacrificial aspects of environmental policy.

\section{B. The Antithetical Rationales: Local Resistance to National Environmental Policies}

The first section of this article described the necessary reliance of federal environmental programs on local implementation and summarized local unwillingness to undertake such implementation. Having catalogued the reasons favoring centralized determination of environmental policies, we are now in a position to understand more precisely the corresponding grounds of state and local resistance to such policies. For the virtues of federal dictation are matched by corresponding vices.

\section{Diseconomies of Scale}

While centralized decisionmaking may be necessary in order to overcome the commons problem and deal with spillovers, it also often generates burdens that are or will appear to be unjustified in particular localities. Federal environmental programs typically place heavy reliance on nationally uniform standards or controls. ${ }^{s 9}$ These uniformities, which reflect both political and administrative constraints in federal decisionmaking, impose economic and social costs

89. Among the factors accounting for such uniformitics are the difficultics of securing legislative consensus on geographically nonuniform measures, legislators' reluctance to delegate to administrators broad discretion over policies profoundly affecting the welfare of their constituents, and the administrative economies of uniform moasures. See Stewart, supra note 17, at 748; Zerbe, Optimal Environmental Juriselictions, 4 EcologY L.Q. 193, $210.12(1974)$. 
on certain areas that are unnecessary or excessive in relation to the benefits obtained. For example, the uniform federal emission limitations on new automobiles impose high costs on rural areas while yielding few compensating benefits. ${ }^{90}$ The nationally uniform technology-based discharge limitations in the 1972 FWPCA create regulatory "overkill" in many areas. ${ }^{91}$ Although the aggregate advantages of federal environmental measures may exceed the costs, particular localities will be loathe to enforce such measures when they involve local burdens that are not offset by local gains.

Even when the federal government utilizes nonuniform measures to deal with spillover problems, the resulting distribution of benefits and burdens may plausibly be regarded as unjust by some of the states affected. For example, requirements of nondegradation in federal air pollution policy limit development in "clean" states for the benefit of citizens in "dirty" states without providing compensation for the sacrifices (in the form of development forgone) thereby imposed on "clean" states." Local inequities (perceived or real) are almost inevitable when Congress attempts to deal with interstate conflicts on a "wholesale" basis through statutes applicable to all states and dealing with a broad class of problems, in contrast to the resolution of such disputes at the "retail" level by courts adjudicating a particular controversy between two states.

\section{The Impairment of Self-Determination}

Environmental interests may well enjoy relatively more influence if environmental decisions are shifted from the state and local to the national level. But this shift is accomplished at the expense of local political self-determination. Decisions about environmental quality have far-reaching implications for economic activity, transportation patterns, land use, and other matters of profound concern to local citizens. Federal dictation of environmental policies depreciates the opportunity for and value of participation in local decisions on such matters. The impairment of local self-determination is considerably aggravated when (as in the transportation control context) local

90. See D. Harrisox, supra note 18, at 91-93.

91. B. Ackerman \& S. Rosf-Ackerman, J. SAwyer, D. HeNderson, The Uncertain SEARCH FOR ENVIRONMENTIL QU.ALITY 326-27 (1974) [hereinafter cited as UNCERTIN SE.SRCH].

92. Since no sectional interest is likely to endure as a permanent majority, however, representatives will tend to follow a spirit of "concurrent majority," avoiding extreme and persistent regional imbalances in the costs and benefits of national policies. See M. V'ILc The Structure of Americin Frderalisid 133-34 (1961). 
fiscal resources and governmental powers are conscripted by federal agencies. Nor is it clear that this loss of self-determination always purchases a net gain in social welfare. Even if unorganized interests (such as environmentalists) are underrepresented at the local level, they may well be, for reasons previously canvassed, overrepresented at the national level. ${ }^{93}$

\section{National Ideals as "Pyramids of Sacrifice"}

Moral crusades enjoy little credit with the nonbelievers who are taxed to underwrite such ventures. Motorists facing drastic curtailment of mobility, ${ }^{94}$ the poor with increased utility bills, and the unemployed in rural areas closed to development ${ }^{95}$ may understandably view the sacrifices they are called upon to make as excessive. Resistance and resentment may be heightened by the fact that many environmental programs distribute the costs of controls in a regressive pattern while providing disproportionate benefits for the educated and wealthy, who can better afford to indulge an acquired taste for environmental quality than the poor, who have more pressing needs and fewer resources with which to satisfy them. ${ }^{96}$ These circumstances may foster, and in part justify, a cynical attitude towards the moral justifications advanced by upper-middle class advocates for environmental programs which benefit that class disproportionately. The impairment of local political mechanisms of self-determination and official accountability involved in federally dictated environmental programs affords further grounds for resentment.

It is not too fine a conceit to mark a parallel between the local impact of national environmental policies and Peter Berger's assessment of the social and moral costs of development in third-world nations. In his book Pyramids of Sacrifice, Berger decries the insensitive willingness of governmental elites to impose severe sacrifices

93. See p. 1218 supra.

94. See Chernow, supra note 38, at $550-51$ (describing burdens EPA threatened to impose on Los Angeles drivers).

95. Studies commissioned by environmental agencics have concluded that the net macrocconomic impact of pollution control requirements has been to increase employment above what it would be in the absence of such requirements. See, e.g., 1976 CEQ REPORT, supra note 7, at 152-55. As the CEQ Report points out, however, this reflects the stimulus of pollution control expenditures in a recession economy. More importantly, a net positive impact on employment nationwide is entively consistent with extremely high rates of unemployment in given regions or among given social or economic groups. Sec Amicus Bricf for Utah Power \& Light Co. at 12-13, Fri v. Sierra Club, 412 U.S. 541 (1973) (claim by Utah utility that an air pollution nondegradation requirement would block development in areas of the state with high levels of unemployment anc: poverty).

96. Sce Stewart, supra note 17, at 715-16 \& n.11. 
on the populace, repressing opposition to such sacrifices on the grounds that they are necessary to "development" but will not be undertaken voluntarily, and that once development has occurred the society will look back upon the sacrifices as justified. ${ }^{97}$ Aspects of national environmental policy might similarly be viewed as the insensitive imposition of sacrifices on local communities, viewed as unjustified by those that bear them (in particular the poor communities), for the sake of a national elite's vision of a better society. ${ }^{98}$ Why should Washington force San Francisco to have cleaner air than it apparently wants?

These several considerations help to explain why local communities might resist federal policies, why local officials might withhold the assistance necessary for their implementation, and why federal environmental programs have accordingly been so unsuccessful in achieving their stated goals. These same considerations are also essential factors in determining the constitutional extent of Congress's power to mandate state assistance in realizing these goals.

\section{Sources of Federal Power to Compel State Implementation of Environmental Policies}

\section{A. Introduction}

The commerce clause affords Congress near-plenary power to require pollution control by private sources. Physical transport of pollutants between states constitutes interstate commerce. ${ }^{99}$ Even where pollution is wholly intrastate, there are several broadly applicable grounds for intervention. Congress might rationally conclude that the adverse effects of intrastate pollution on human health, vegetation, resources, and industrial processes have a depressing effect on production and consumption related to interstate markets. Alternatively, it could impose stringent environmental controls in all states in order to eliminate the actual or potential competitive advantage enjoyed by firms in states with lax controls over firms in states that have or would otherwise prefer to adopt stringent controls. ${ }^{100}$ To the extent

97. See P. Berger, Pyrimins of SACrifice 10-11, 90-91, 128-29 (1976).

98. See Wildarsky, Aesthetic Pouer or the Triumph of the Sensitive Minorily Ovcr the Vulgar Mass, in Pollution ANo Pcblic Policy 37, 44-45 (D. Paulsen \& R. Donharclt c(s. 1973).

99. South Terminal Corp. v. EPA, 50.t F.2d 646, 677 (Ist Cir. 1974); United States v. Bishop Processing Co., 287 F. Supp. 624, 629-32 (D. Md. 1968), aff'd, 423 F.2d 469 (4th Cir.), cert. denied, 398 U.S. 904 (1970).

100. A similar rationale was utilized in United States v. Darby, 312 U.S. 100, 115, 122 (1941), to sustain imposition of federal minimum wage and maximum hour requirements. 
that a pollution source uses or consumes goods produced in interstate commerce, Congress can require that such sources either undertake controls or forswear the fruits of that commerce. ${ }^{101}$ Congress's broad jurisdiction over the waters of the United States (based in part on the commerce power) provides yet another ground of pollution control authority. ${ }^{102}$ Finally, the fact that pollution damage is frequently attributable to emissions from a large number of small sources ${ }^{103}$ would support Congress's authority to deal with potential objects of the commerce power on a "class" basis. ${ }^{104}$ These bases of congressional power make it most unlikely that any private source of pollution would not be subject to federal control under prevailing conceptions of the commerce power.

Nor would any of the reasons that we have examined for local discontent with national environmental policies afford private sources grounds for objection to Congress's use of the commerce porver to enforce those policies against them. Any argument that congressional policies impose costs greater than their benefits, or favor some localities or interest groups over others, would be unavailing. Individuals and firms are subjects of national authority, and the national political arena is their only remedy for the asserted stupidity or inequity of Congress's otherwise valid exercises of the commerce power. ${ }^{105}$

But the matter would be very different were Congress to invoke the commerce power as a justification for compelling state and local governments to implement federal environmental policies. There is no close precedent, historical or legal, supporting such an undertaking. Its validity is cast in doubt by $N L C,{ }^{106}$ which denied Congress constitutional authority under the commerce clause to impose minimum

10l. Cf. Katzenbach v. McClung, 379 U.S. 291, 298, 299-305 (1964) (Title II of the Civil Rights Act of 1964, Pub. L. No. 88-352, 78 Stat. 241, upheld as applied to restaurant receiving food which mored in interstate commerce).

102. See Soper, The Constitutional Framework of Environmental Law, in FEDERAL ENvironmextal L.Aw, supra note 1 , at 20, 25, 29-30.

103. Cf. Wickard v. Filburn, 317 U.S. 111, 127-29 (1942) (individual farmer's wheat crop destined for on-farm consumption is subject to commerce power regulation because its impact on interstate commerce, taken together with other similarly situated farmers, is nontrivial).

104. See Perez v. United States, 402 U.S. 146 (1971) (federal sanctions on loan sharking upheld since prohibited activity belongs to class-organized crime-with impact on interstate commerce).

105. See Lottery Case, 188 U.S. 321, 363 (1903). However, if the Constitution imposes federalism limitations on national power in order to protect state autonomy in the regulation of private activity, individuals might lave standing to enforce such limitations. See p. 1270 \& note 250 infra.

106. 426 U.S. 833 (1976). 
wage and maximum hour requirements on state and local governments because such requirements unduly burdened the state autonomy implicitly preserved and protected by the federal Constitution. NLC in turn finds precedential support in the decisions acknowledging special constitutional limits (limits which remain undefined but unrepudiated) on the federal taxing power when directed at state governments. ${ }^{107}$ Behind both $N L C$ and the taxing cases lie half-explored assumptions as to the definition and extent of the states' role in our governmental system.

That role, however minimally conceived, could be destroyed if state and local governments were as fully subject to the commerce power as private firms and individuals and if Congress pressed the power to its limit. On these assumptions, Congress could require states to abandon their systems of economic and social regulation and force them to implement substitute policies dictated by Washington. ${ }^{108}$ It could also use the commerce power (together with measures plausibly deemed necessary to protect the federal taxing power) to preempt most forms of state and local taxation. ${ }^{109}$ In theory, state and local governments could be reduced to mere appendages of the federal government, nourished by such revenues as the federal government deigned to provide. No one can doubt that such a result would transgress the constitutional scheme. Principles of federalism inherent in that scheme must impose limits on Congress's exercise of otherwise plenary national powers against the states.

107. Id. at 843. See New York v. United States, 326 U.S. 572, 586-90 (1946) (Stone, C.J., concurring in the result) (citing cases).

The New York decision upheld a federal tax on New York State's sales of mincral waters. The six Justices voting to sustain the tax split 4-2 as to rationale, with both opinions agreeing that the state sovereignty considerations opcrated to limit the reach of Congress's taxing power. Speaking for four members of the Court, Chief Justice Stone warned that even "nondiscriminatory" taxes on state activities might be struck down if they "interfere[d] unduly with the States performance of its sorereign functions of government." Id. at 587. Justices Frankfurter and Reed rested their support for the constitutionality of the mineral waters tax on the fact that it did not reach income "uniquely capable of being earned only by a state"; they distinguished this type of enactment from taxation of "the State as a State," citing as examples of the latter levies on a statehouse or tax-derived state income. Id. at $\mathbf{5 8 2}$ (opinion of Frankfurter, J.). And as the NLC opinion pointed out, dissenting Justices Black and Douglas "adrocated a position even more protective of state sovereignty than that advanced by Stonc." 426 U.S. at 843 n.13.

108. However, federal legislation preempting state regulation has been upheld even though it displaces important state and local policics. See p. 1243 infra.

109. State excise taxes and taxes on business activity sufficiently affect interstate commerce to be subject to federal proscription on a class basis if decisions governing federal regulation of private activity, such as Wickard v. Filburn, 317 U.S. 111 (1942), were fully applicable to federal regulation of state governmental activities. In addition, the Congress might preempt other forms of state taxation, such as the personal income tax, in order to protect the federal tax base. 
Whether such limits are justiciable presents, however, a serious question. Despite $N L C$, there are strong grounds for concluding that the restraints on national power implicit in our federal structure should, like the guaranty clause, remain nonjusticiable. ${ }^{110}$ These grounds will be examined in the final section of the article; for present purposes, federalism limitations are assumed to be judicially enforceable. ${ }^{111}$

\section{B. The Justifications for Federally Mandated State Implementation of National Policies}

There is a dearth of authoritative precedent regarding Congress's power to mandate state implementation of transportation controls in particular and environmental measures generally. The limits on that power are best elucidated by resort to analogy, hypothetical example, and certain implications derivable from NLC. The nature of the potential justifications for federal environmental measures and the precise ground of state resistance to them are also relevant. Unless the contours of federalism limitations are to be determined through an ad hoc balancing process of the sort apparently envisaged by Justice Blackmun in his NLC concurrence, ${ }^{112}$ it is imperative to structure the competing constitutional values at stake. Drawing upon the analysis of this article's previous section, the justifications for fed-

110. See Georgia v. Stanton, 73 U.S. (6 Wall.) 50 (1868) ("republican form of government" claim nonjusticiable). However, in Brown v. EPA, 521 F.2d 827, 840 (9th Cir. 1975), vacated and remanded per curiam, $97 \mathrm{~S}$. Ct. 1635 (1977), the court indicated in dictum that the guaranty clause might be applied to bar undue federal interference with state legislative and fiscal autonomy.

111. The question of standing raises separate issues. The general rule is that states do not have standing to assert the interest of their citizens in avoiding assertedly unconstitutional federal statutes. Florida v. Mellon, 273 U.S. 12, 18 (1927); Massachusetts v. Mellon, 262 U.S. 447, 485.86 (1923). But in Missouri v. Holland, 252 U.S. 416 (1920) (upholding federal restrictions on taking of game birds as ralid incident of treaty-making power), the Supreme Court did not dispute the petitioning state's capacity to attack a federal statute on the ground that the enactment assaulted prerogatives of state sovereignty. And in South Carolina v. Katzenbach, 383 U.S. 301 (1966), the Court allowed South Carolina to challenge the constitutionality of federal statutes suspending the states' literacy tests for voting, requiring federal approval of changes in the state's election laws, and providing for federal voting registrars for state elections. These decisions could provide a basis for affording standing to states challenging federal requirements that states implement national environmental policies. In any event, state officials subject to sanctions for refusing to obcy such requirements would clearly have standing to challenge the requirements' validity; and under the relaxed ripeness requirements of Abbott Laboratories v. Gardner, 387 U.S. 136 (1967), such review could be obtained in advance of the actual imposition of sanctions. See Brown v. EPA, 521 F.2d 827, 831 (9th Cir. 1975), vacaled and remanded per curiam, 97 S. Ct. 1635 (1977).

112. See 426 U.S. at 856 (Blackmun, J., concurring). 
erally mandated state implementation of federal environmental measures can be grouped into three categories.

\section{Intrastate Welfare}

Mandating state enforcement of federal controls may be justified as enhancing the welfare of that state's residents by (a) overcoming the commons problem or other diseconomies of noncentralized decision; or (b) correcting for an "overrepresentation" of polluter interests in state political processes which may lead to the adoption of policies that are suboptimal for the welfare of the state as a whole. Either rationale would amply sustain a commerce clause enactment directed against private individuals; reviewing courts need only be shown "a rational basis for finding a chosen regulatory scheme necessary to the protection of commerce."113

When it is states that are the targets, however, an argument justifying an exercise of federal power by reference to induced internal welfare gains becomes suspect in the face of vigorous resistance by the supposed beneficiary. Such obduracy is prima facie evidence that, in the particular case at issue, the benefits to the state of federal policies are outweighed by the costs. ${ }^{114}$ While recalcitrance might be discounted as reflecting the continued local political overrepresentation of organized interests that stand to profit from environmentally disruptive activities, it could with equal plausibility be attributed to overrepresentation of environmental interests in federal policies.115 For reviewing courts, it will be highly problematic whether a protesting state's welfare will be advanced by implementation of federal environmental programs. Moreover, such coercion represents a serious intrusion on local mechanisms of self-determination and political accountability. The intrastate welfare justification is therefore a weak one.

\section{Spillover Effects}

Where a state is called upon to implement federal controls in order to prevent spillover effects in other states, a far stronger case

113. Katzenbach v. McClung, 379 U.S. 294, 303-04 (1964).

114. In its brief to the Ninth Circuit in Brown v. EPA, the State of California vigorously argued that the net impact of federal transportation policies on intrastate welfare would be overwhelmingly negative, citing wage losses, damage to service, retail, and manufacturing industries, and "the likelihood of 'unreasonable changes in the life style of [affected] regions and . . . the paralysis of entire urban areas." "Brief for Petitioner at 34-35, Brown v. EPA, 521 F.2d 827 (9th Cir. 1975) (quoting EPA White Paper, The Clean Air Act and Transportation Controls 30 (1973)).

115. See p. 1218 supra. 
exists for subordinating state autonomy to federal commands. State decisionmaking is likely to disregard spillovers whose costs will be borne by other states. Moreover, federalism implies its own version of the categorical imperative: within the context of a federal system of co-equal states, a state's claim to autonomy is entitled to respect only insofar as it allows a like autonomy for sister states. Accordingly, a state should not be entitled to invoke the principle of local self-determination against federal controls where that state generates significant spillovers which impair the corresponding ability of sister states to determine the environmental quality they shall enjoy. This conclusion is fortified by decisions authorizing federal court suits by states to redress harms to their citizens emanating from sister states. ${ }^{116}$ As developed below, ${ }^{117}$ the principles supporting such relief imply a reciprocal liability for a state when harmful spillovers are generated within its borders.

The potential sources of federal power to regulate spillovers are several. The commerce clause, as noted earlier, subjects interstate pollution to congressional control. Where that power is directed against spillovers attributable to a state or local government, the categorical imperative of federalism-a corollary of $N L C$-should sustain federal authority against claims of infringed state autonomy.

Congress's capacity to deal with spillovers also flows by implication from the recognized powers of federal courts to resolve interstate disputes. In Illinois v. City of Milwaukee, ${ }^{11 s}$ the Supreme Court approved the creation of a federal common law of interstate pollution to govern controversies between states over the discharges of municipal sewers; it plainly implied power in the federal courts to impose coercive relief on the officials of the responsible state instrumentalities. ${ }^{110}$ Earlier Supreme Court decisions, some of which belong to the era of "dual federalism," 120 specifically authorized federal judges to impose coercive controls on state officials to prevent interstate water pollution and analogous spillovers. ${ }^{121}$

116. See, e.g., Georgia v. Tennessee Copper Co., 206 U.S. 230 (1907); see generally P. Bator, P. Mishikin, D. Shapiro \& H. Wechsler, Hart \& IVechsler's The Federal Courts AND THE Feder.al Systrar 270-75 (2d ed. 1973) (citing cases) [hereinafter cited as Hart \&. WECHSLIR].

117. See p. 1248 infra.

118. 406 U.S. 91 (1972).

119. Id. at 108 (remitting parties to "an appropriate district court whose powers are adequate to resolve the issues" (footmote omitted)).

120. For a discussion of the concept, which casts the federal government and the states as equal sovercigntics destined for continual competition, see Corwin, The Passing of Dual Federalism, 36 VA. L. Rev. 1 (1950).

121. See Ncw Jersey v. City of New York, 283 U.S. 473 (1931) (dumping garbage in ocean); Wisconsin v. Illinois, 278 U.S. 367 (1929), report of master confirmed, 281 U.S. 
Federal court jurisdiction that confers power on the federal judiciary to fashion a federal common law of interstate pollution implies a similar power in Congress to enact statutes to govern such problems. The legislative supremacy of Congress includes the power to revise judge-made federal common law. ${ }^{122}$ This revisory power, well established in the field of maritime law, ${ }^{123}$ appears equally justified when applied to the law governing interstate spillovers. ${ }^{124}$ To be sure, Congress's "wholesale" treatment of such spillovers through general statutory provisions may be less sensitive to individual issues of state autonomy than "retail" disposition of particular controversies by the courts. ${ }^{125}$ But individual litigation between the states would be an inadequate and unsatisfactory way of dealing with spillovers, particularly in the case of long-distance transport of pollutants across many states. ${ }^{126}$ The complex nature of spillover problems accordingly reinforces congressional power to supplement or supplant through general legislation judicial remedies for interstate spillover conflicts.

Congressional control of interstate spillovers is supported by a final consideration: the inherent power of Congress to take measures reasonably necessary for preserving the system of union. Spillovers have and will continue to create tensions among the states. ${ }^{127}$ As economic development proceeds and populations grow, interstate pollution will

179 (1930) (diversion by Illinois of water from Lakc Michigan); Missouri v. Illinois, 180 U.S. 208 (1901) (sewage). Cf. Sanitary Dist. v. United States, 266 U.S. 405 (1925) (affirming power of federal government to enjoin municipal withdrawals of water from Lakc Michigan for waste disposal purposes).

122. See Monaghan, The Supreme Court, 19\%f Term-Foreu'ord: Constilulional Common Law, 89 Harv. L. Rrv. 1, 10-11 (1975). See also Arizona v. California, 373 U.S. 546, 565-67 (1963) (congressional statute controls decision of interstate controversy otherwise controlled by judge-made federal common law).

123. See Note, From Judicial Grant to Legislative Power: The Admiralty Clatse in the Nineteenth Century, 67 Harv. L. Rev. 1214, 1230-37 (1954).

124. In Illinois $v$. City of Milwaukce, 406 U.S. 91, 107 (1972), the Supreme Court indicated in dictum that judge-made federal common law gorcrning interstate pollution was subject to revision by congressional legislation.

125. On the other hand, Congress may be more sensitive than the courts to state claims that federal controls on spillovers are unduly burdensome. See Stewart, supra note 17 , at $748 \cdot 49,757-58$.

126. For discussion of the limitations of litigation as a means of dealing with pollution, particularly where multiple sources and recipients are involved, sce J. KrRIER, supra note 78, at 208-32. See also Ohio $v$. Wyandotte Chemicals Corp., 401 U.S. 493, 50105 (1971). While litigation by a state to protect the welfare of its citizens parens patriae, see Missouri v. Illinois, 180 U.S. 208, 241 (1901), would alleviate some of the shortcomings of private litigation by "collecting" the interests of many individuals in the position of plaintiffs, difficult problems of establishing causation and of remedy remain where pollution emanates from multiple sources in many states. Sulfate pollution in the eastern states, for example, is in substantial part attributable to emissions from sources hundreds of miles to the west. See note 76 supra.

127. See Ohio v. Wyandote Chemicals Corp., 401 U.S. 493, $496-97$ (1971) (citing cases). 
increase, and with it the potential for retaliatory tactics and litigation. Congressional power to mitigate these tensions through preventive legislation is implicit in the very decision to replace a loose confederation hamstrung by interstate friction with a strong national government. That power, like the original jurisdiction of the Supreme Court, may be asserted to resolve authoritatively the tensions inevitable in a union of states with frequently conflicting autonomy claims. ${ }^{128}$

There remain important questions as to the quantum of interstate effects required to justify federal regulation of spillovers. Recognizing the legitimacy of state autonomy values, the spillovers required to justify federal coercion of the states should be substantial-more substantial than those required to support the exertion of the federal commerce power against private firms or individuals. The required substantiality should be defined in accordance with the proposed rationale for federal intervention-the regulation and maintenance of the system of union. In order to support congressional coercion of state officials, the invasion of one state's interest by another should be sufficiently grave that it might otherwise provoke litigation between the states involved or, if transposed to an international context, create discernible strains in relations between sovereign states. ${ }^{129}$

Even in the case of substantial spillovers, federal courts may be

128. H.IRT \& WEChSLER, supra note 116 , at 263-64.

129. A rationale for the Supreme Court's jurisdiction over interstate disputes, and for the derivative power of Congress to enact laws to resolve or prevent such disputes, is to furnish a means of resolving conflicts decided by force or diplomacy in the case of independent nations. See Georgia v. Tennessee Copper Co., 206 U.S. 230, 237 (1907) (sustaining a state's standing parens patriae to sue for an injunction against pollution from another state) (emphasis in original):

When the States by their union made the forcible abatement of outside nuisances

impossible to each, they did not thereby agree to submit to whaterer might be done.

They did not renounce the possibility of making reasonable demands on the ground of their still remaining quasi-sovereign interests; and the alternative to force is a suit in this court.

In accordance with this rationalc, only significant spillovers of a sort that might provoke confrontation between sovereign states (such as the current dispute between Sweden and Britain over the latter's sulfate pollution) should justify federal intervention. See Missouri v. Illinois, 200 U.S. 496, 520-26 (1906). The Supreme Court has required "clear and convincing evidence" that the injury done by one state to another is of "scrious magnitude" before affording relief. Id.; accord, Connecticut v. Massachusetts, 282 U.S. 660, 669 (1931); New York v. New Jersey, 256 U.S. 296, 309 (1921). The same principle should apply to Congress's imposition of prophylactic measures. There are difficulties, however, in applying this standard to cases of actual or potential spillovers (such as releases from a nuclear power plant "meltdown") that present an uncertain risk of scrious harm, particularly if the "recipient" state's residents are more risk averse than residents of the originating state. Cf. Ethyl Corp. v. EPA, 541 F.2d 1, 20-25 (D.C. Cir.), cert. denied, 426 U.S. 941 (1976) (en banc) (discussing frequent necessity that pollution control decisions be made under conditions of uncertainty, and upholding wide discretion in EPA to assess risks under such circumstances). 
asked to judge the constitutionality of congressionally mandated cleanup measures by weighing the burdens imposed on originating states against the resulting benefits to receiving states in particular instances. It is an invitation they should refuse. Because of political and administrative constraints, Congress must often deal with spillover problems in a generic fashion. A case-by-case judicial determination of whether federal statutory impositions on states were warranted in particular instances would, in effect, make the judge-made common law of interstate pollution superior to congressional statute. ${ }^{130}$ It would also loose the bonds of compromise that may have been politically indispensable for the enactment of such a statute in the first place. ${ }^{131}$ The resolution of substantial interstate conflicts should be left in the hands of the national forum in which all states are represented under the formula of the Great Compromise.

\section{National Moral Ideals}

When significant interstate spillovers are absent and intrastate welfare justifications remain weak, mandatory state implementation of federal environmental programs may nonetheless be justified as a necessary element in a "politics of sacrifice" directed toward national goals. Congressional authority to use the commerce power in the service of moral ideals is long-established. ${ }^{132}$ It may only be in the context of a nationwide commitment that individuals or communities will be persuaded mutually to forgo consumption in order to fulfill duties to the weak and vulnerable or preserve the inheritance of future generations. The most serious vice of a liberal society is the comfortable complacency that serves as veneer for narrow self-interest. Nationally determined policies may be indispensable engines of moral change.

130. While congressional resolution or prevention of interstate conflict on a "wholesale" basis may be less sensitive to interests in state autonomy than judicial resolution of particular disputes at "retail," see p. 1228 \& note 125 supra, the difference should not be of constitutional significance, particularly in view of the limited efficacy of adjudication in dealing with interstate pollution. See note 126 supra.

131. Congressmen might be reluctant to overcome the environmental commons problem by agreeing on uniform federal policies if there is a substantial possibility that the federal courts would sustain the application of these policies to some states but not to others.

132. See Hoke v. United States, 227 U.S. 308 (1913) (white slave traffic); Lottery Case, 188 U.S. 321, 355-58 (1903) (exclusion of lottery tickets from interstate commercc); W: Lockhart, Y. Kimisar \& J. Choper, The Amrricin Constiturion 118-20 (1970). See also United States v. Darby, 312 U.S. 100, 114 (1911) ("Congress, following its own conception of public policy concerning the restrictions which may appropriately be imposed on interstate commerce, is free to exclude from the commerce articles whose use in the states for which they are destined it may conceive to be injurious to the public health, morals or welfare ....") 
But there are powerful moral counterarguments for local autonomy. Centralized dictation may represent at best paternalism, at worst a usurpation of local self-determination in order to advance the interests or tastes of a societal elite. Moreover, almost any federal measure could be rationalized in terms of some moral objective. Either this would imply that all such interventions are constitutional, eliminating federalism limitations on national power, or judges would face the difficult task of deciding which federal programs were sustained by sufficiently weighty moral goals to justify intrusions on local selfdetermination.

The moral justifications for and against national power to coerce the states are in close balance. The ultimate resolution cannot be determined without examining the practical implications of recognizing constitutional power in the federal government to compel state cooperation and considering the availability of less burdensome alternatives for achieving national goals.

\section{Countervailing Interests in Local Autonomy: \\ The Constitutional Dimension}

Arrayed against the several justifications for federally mandated state controls are important values of local self-determination in the selection of environmental policies and the deployment of local governmental resources. As outlined earlier, ${ }^{133}$ these values include the greater sensitivity of local officials to the preferences of citizens and the costs of achieving environmental goals in a given locality; the diffusion of governmental power and the promotion of cultural and social diversity; and the enhancement of individual participation in and identification with governmental decisionmaking.

In order to secure these values implicit in our federal structure of government, two aspects of state and local political autonomy merit constitutional protection. The first is the liberty to determine the structure of state and local governmental decisionmaking machinery and the concomitant capability to operate that machinery. The states should, for example, enjoy the liberty to decide whether the state legislature should be bicameral or unicameral, the location of the state capital, ${ }^{\mathbf{1 3}}$ the degree of home rule accorded political subdivi-

133. See pp. 1210-11 supra.

134. See Coyle v. Smith, 221 U.S. 559 (1911) (quoted in National League of Cities v. Usery, 426 U.S. 833,845 (1976)). 
sions, and the organization of the executive and judicial branches. ${ }^{135}$ The states should likewise be protected against federal impositions, such as discriminatory or unduly burdensome taxation of state buildings, that could threaten the viability of state and local government. ${ }^{136}$

The second protected aspect of state autonomy is the determination of what goods and services state and local governments should pro. vide their citizens and how these measures should be financed. Included here are decisions as to the level, mix and distribution of various governmental benefits, and the capability to provide these benefits by levying taxes or otherwise raising revenues, hiring state employees, contracting for supplies, and wielding sanctions. NLC acknowledged that the structuring and delivery of certain traditional governmental services, such as education, sanitation, and police and fire protection, were "integral," and therefore entitled to constitutional protection. ${ }^{137}$ But other traditional local functions, including the provision of a higher quality environment through zoning or other regulation of private conduct, equally serve federalist values of noncentralized decisionmaking and therefore should enjoy comparably privileged status. ${ }^{138}$ Moreover, state and local decisions not to provide such benefits and not to levy taxes or regulate private conduct for that purpose should also receive constitutional protection, for the choice between private and public modes of decision and allocation is a fundamental aspect of political autonomy supported by federalist values.

The first protected aspect of local autonomy (the structure and operation of the decisionmaking machinery of government) is weightier because it is more basic and logically prior to the second (decisions as to which goods and services government should provide its citizens). Of course, in a federal structure neither aspect of state or local autonomy can be constitutionally absolute because of the competing claims of national decisionmaking. ${ }^{139}$

135. But cf. Oklahoma v. United States Civil Service Comm'n, 330 U.S. 127 (1947) (Congress may require, as a condition of federal highway grants to state, that state highway officials refrain from partisan political activities.)

136. See the several opinions in New York v. United States, 326 U.S. 572 (1946), discussing in dicta the constitutional limits on Congress's power to levy taxes on state office buildings, id. at 582 (opinion of Frankfurter, J.); id. at 587-88 (Stone, C.J., concurring in the result).

137. See 426 U.S. at 851-52.

138. See pp. 1267-68 infra.

139. See, e.g., Oklahoma v. United States Civil Service Comm'n, 330 U.S. 127, 143 (1947) (declining to invalidate conditions on federal grants which prohibited partisan 
D. Testing the Justifications for Federal Power:
Four Representative Cases

In order to elucidate the conflict between the various justifications for federal conscription of state enforcement resources and the countervailing considerations of local autonomy, consider four types of cases in which Congress might seek to require a state to control pollution:

1. Air pollution from a municipal electric generating plant;

2. Water pollution from a municipal sewage waste treatment plant;

3. Air pollution generated by private automobiles utilizing urban roads;

4. Pollution from privately owned industrial sources that is not generated on or by state-owned facilities.

\section{The Municipal Power Plant}

A municipality constructs an electric power plant whose product is sold to private customers within the municipality. ${ }^{140}$ The federal EPA brings an action to force the local officials responsible for operating the plant to install controls on air pollution in order to bring the plant into compliance with applicable federal regulations. Do federalism limitations recognized in $N L C$ preclude federal enforcement actions?

If federal controls on an identical privately owned plant would be valid under the commerce clause, they should likewise be sustained where the plant is owned by a state or local government.141 There are important considerations that distinguish the power plant case from NLC. Furthermore, it would be unwise to extend the federalism protections to preclude federal control of emissions from state or municipal power plants.

political activities by state officials responsible for administering the grants on the ground that Congress has "the power to fix the terms upon which its money allotments to the states shall be disbursed").

140. National League of Cities v. Usery, 426 U.S. 833 , 855 n.20 (1976), held that political subdivisions of a state share in the state's immunity from congressional exercises of the commerce power that would impair "integral" state and local functions. But cf. Mount Healthy City School Dist. Bd. of Educ. v. Doyle, 97 S. Ct. 568, 572-73 (1977) (local school board does not share in state's Eleventh Amendment immunity).

141. See Brief for the States at 38 n.61, EPA v. Brown, 97 S. Ct. 1635 (1977) (states challenging EPA authority to compel state enforcement of transportation controls concede that "direct pollution by the state from a stationary source, such as an incinerator, may be the subject of EPA sanction"). 
$N L C$ 's special solicitude was reserved for " 'functions essential to separate and independent existence" "1+2 of the states and to the "integral portion of those governmental services which the States and their political subdivisions have traditionally afforded their citizens." 143 These passages offer little guidance in determining whether municipal power production is protected against federal control, particularly in view of the fact that numerous municipalities have long engaged in power production. ${ }^{144}$ However, $N L C$ and the precedent upon which it draws seem to include only the actual conduct of governmental decisionmaking and the provision of a nineteenth century core of protective, educational, and health services within the sphere that is constitutionally protected against burdensome federal requirements. ${ }^{145}$

As Professor Michelman points out, ${ }^{146}$ there is no apparent logical basis for this demarcation. If (as seems to be the case in $N L C$ ) state autonomy is valued because it facilitates local self-determination and experimentation, why shouldn't state efforts to alter traditional allocations between private and public enterprises in the provision of

142. 426 U.S. at 845 (quoting Lane County v. Oregon, 74 U.S. (7 Wall.) 71, 76 (1869)). 143. Id. at 855 (footnote omitted).

144. As pointed out by Justice Brennan in his $N L C$ dissent, $i d$. at $872-75$, the majority opinion affords painfully inadequate guidance for determining what government functions are or are not included within the protected sphere. Apart from stating that certain functions are included (fire prevention, police protection, sanitation, public health, and parks and recreation) and certain functions excluded (running a railroad), the Court refers to the "integral portion of those governmental services which the States and their political subdivisions have traditionally afforded their citizens." Id. at 855 (footnote omitted). The inherent difficulties in such an approach were well expressed by Justice Frankfurter in the analogous context of state immunity from federal taxation. To define the protected class of state activities by reference to the functions performed by states at some fixed point in history reflects "a static concept of government" that "denies its essential nature." New York v. United States, 326 U.S. 572, 579 (1946) (plurality opinion of Frankfurter, J.) Yet to "rest ... on what is 'normally' conducted by private enterprise in contradiction to the 'usual' governmental functions is too shifting a basis for determining constitutional power and too entangled in expediency to serve as a dependable legal criterion." $I d$. at 580 . But it is not clear that there is any more satisfactory alternative to the polar extremes of subjecting state activity to federal control whenever comparable activity is carried on by private actors and could be federally taxed or regulated, see id. at 582, or immunizing any activity when it is undertaken by the state, $i d$. at 591.92 (Douglas, J., dissenting). These difficulties counsel a minimal role for courts in defining and enforcing federalism limitations on congressional power. See pp. $127 \mathrm{I}-72$ infra.

145. The Court overruled Maryland v. Wirtz, 392 U.S. 183 (1968), thus invalidating the federal Fair Labor Standards Act as applied to state hospitals and educational institutions, but reaffirmed Parden v. Terminal Ry., 377 U.S. 184 (1964), California v. Taylor, 353 U.S. 553 (1957), and United States v. California, 297 U.S. 175 (1936), which had sustained federal regulation of state-owned railroads. 426 U.S. at $853-55,854$ n.18. In discussing the last case, the Court asserted that operation of railroads was not an "area that the States have regarded as integral parts of their governmental activities." Id. at 854 n.18.

146. Michelman, States' Rights and States' Roles: Permulations of "Sovereignty" in National League of Cities v. Usery, 86 YALE L.J. 1165, $1168-69$ (1977). 
services be awarded comparably privileged status under federalism principles? ${ }^{147}$ Why should state activities receive constitutional protection only if confined within narrow conceptions of governmental function enunciated by the federal judiciary? The only obvious retort is that some arbitrariness is probably inevitable in any effort to give justiciable content to federalism limitations on national power.

Distinguishing the power plant case from the measures involved in $N L C$ is the limited focus and impact of the federal incursion. True, installation of the required controls may entail substantial expenditures. But the state retains the plausible option of withdrawing from the power generation business, ${ }^{148}$ leaving intact the "integral" functions only government can discharge. In $N L C$, by contrast, the burden of federal wage and hour requirements was imposed on nearly all state governmental functions, including many within the "integral" category. The Justices accordingly viewed wage and hour requirements as differing only in degree from federal measures that would effectively reduce state and local governments to federal appendages. That danger is absent here.

A further potential distinction is suggested by Justice Blackmun's concurrence in $N L C$, characterizing the decision as a "balancing approach" which "does not outlaw federal power in areas such as environmental protection, where the federal interest is demonstrably greater and where state facility compliance with imposed federal standards would be essential." 140

In what sense might the "federal interest" and the necessity for state compliance be greater in control of power plant pollution than in wage and hour regulation? If the balancing suggested by Justice Blackmun were to be utilitarian in character, the court would first

147. See New York v. United States, 326 U.S. 572, 590-98 (1946) (Douglas, J., concurring) (inveighing (in the context of a taxation case) against federal measures that could inhibit state experimentation with new forms of economic organization, including public ownership of enterprises traditionally within the private sector).

148. In the case of state industrial facilities producing goods or services for which a charge can be exacted, the state can avoid the burden of federal controls by transferring the facility to private ownership. Alternatively, the state can retain ownership of the facility but pass the economic burden of federal controls on to consumers in the form of higher prices. See Wilmette Park Dist. v. Campbell, 338 U.S. 411, 419-20 (1949) (refusing to invalidate a federal tax on tickets for admission to a municipal park because of the municipality's ability to pass on the burden of the tax). Either of these alternatives would involve increases in the price of the goods and services in question, but the state could provide a subsidy to offset the costs attributable to federal pollution control requirements. The states' interest in avoiding these requirements in order to subsidize consumers at the expense of those suffering damage from pollution should not be entitled to great weight.

149. 426 U.S. at 856 (Blackmun, J., concurring). 
calculate the net social benefits generated by state compliance with federal requirements and then determine whether these outweighed the losses occasioned by federal interference with state autonomy. ${ }^{150}$

This approach might be justified by analogy to commerce clause and implied preemption cases, where federal courts appear to have employed a rough utilitarian calculus in reconciling competing claims of state and national policy. ${ }^{151}$ But the analogy is flawed. In the commerce clause and implied preemption cases, Congress has not explicitly spoken and the courts, faute de mieux, must weigh the utility of national freedom of commerce or general congressional policies against specific state measures. But where Congress has (as in NLC) uttered an unambiguous command, the courts can pursue the suggested "balancing" approach only if they are prepared to secondguess the utilitarian calculus ("wisdom") of Congress. As Justice Brennan points out in his $N L C$ dissent, ${ }^{152}$ the courts have foresworn such second-guessing in other contexts, and to resurrect it here could involve the judiciary in potentially hazardous confrontations with the political branches. Moreover, while some of the justifications for state autonomy and decentralized decisionmaking are utilitarian in character, others, such as self-determination, are not. Comparing the utility gains from state compliance with federal programs with losses to state autonomy is like the proverbial comparison of apples and oranges. ${ }^{153}$

Justice Blackmun might be understood, however, as making the question of federal supremacy turn not on the weight but on the nature of the federal interest advanced to justify state submission. ${ }^{15 t}$ Such an approach might involve the three previously-elaborated categories

150. Justice Blackmun seems to assume that the net benefits from state compliance with federal environmental measures are high and are likely to outweigh fecleralism losses, while the net benefits from wage and hour regulation are quite low. See id.

151. See Bibb v. Narajo Freight Lines, 359 U.S. 520 (1959); Southern Pac. Co. v. Arizona, 325 U.S. 761, 770-84 (1945).

152. See 426 U.S. at 859-63, 867-68, 876-78 (Brenman, J., dissenting).

153. It may be objected that cases in which state regulations or taxes are challenged as violative of the commerce clause or as preempted by federal statute likewise involve an apples and oranges comparison. However, the courts often engage in a thoroughgoing utilitarian calculus to resolve the issues involved without considering claims of state autonomy as such. See p. 1236 \& note $15 \mathrm{I}$ supra. This practice may to some extent be justified because the effective invasion of state autonomy is less when state policies arc displaced than when the state is affirmatively required to exccute federal policies. Sec pp. 1243-44 infra.

154. For use of classificatory as opposed to "balancing" tests in constitutional adjudication, see Board of Regents v. Roth, 408 U.S. 564 (1972); Ely, Flag Desecration: A Case Study in the Roles of Categorization and Balancing in First Amendment Analysis, 88 HARv. L. REv. 1482 (1975); and Ely, The Irrepressible Myth of Erie, 87 H.ARv. L. REv. 693 (1974). 
of justification for federal conscription of State officials. The existence of substantial spillovers, for example, would afford conclusive grounds for the assertion of federal authority. On the other hand, if the only justification for federal authority were advancing the welfare of those within the state, it would not support the imposition of serious burdens on integral state functions.

But these justifications need not be reached. As argued above, the municipal power plant case does not involve the type of federal impairment of state functions that confronted the Court in $N L C$. In general, federal controls on state-owned industrial facilities that are identical to those imposed on similar privately owned facilities will not create the sort of incursions on state autonomy that trigger federalism limitations on national power and the corresponding need for special justifications for federal authority.

\section{Municipal Waste Treatment Plants}

The 1972 FWPCA requires installation of expensive controls on water pollution from municipal waste treatment plants. Do we deal here with an essential state/local governmental function within $N L C$ 's protected core? Certainly sanitation has been for centuries a traditional municipal responsibility, fully as vital to citizens' health and safety as police and fire protection. Indeed, the $N L C$ opinion explicitly places sanitation within the essential protected core of local services. ${ }^{155}$ The financial burden imposed on state and local governments by federal controls would be vast (and often regressive in its distributional impact) ${ }^{156}$ and difficult for localities to avoid by withdrawing from the field of providing waste treatment services. While it may seem rather bizarre to distinguish a city's waste pollution so sharply from its air pollution, $N L C$ and the need for inevitably arbitrary line drawing in defining protected local governmental functions makes federal water pollution controls on municipal sewage constitutionally suspect.

Accordingly, the potential justifications for such controls must be addressed. Our earlier analysis ${ }^{157}$ and the $N L C$ decision itself suggest that intrastate welfare considerations alone could not serve as a justification. This conclusion is buttressed by limited empirical evidence indicating that most local citizens (particularly the poor) would

155. 420 U.S. at 8501 .

156. It is estimated that cumulative expenditures by state and local governments of S155.4 billion will be required during the $1975-1984$ period in order to meet federal water pollution control requirements. 1976 CEQ REPORT, supra note 7, at 167 (estimate in 1975 dollars).

157. See p. 1226 supra. 
not, when squarely put to the choice, be willing to spend the funds required to implement federal programs for municipal waste treatment. ${ }^{158}$

The earlier analysis, however, provides powerful grounds for federal intervention if municipal water pollution within the state generates spillovers in other states, even if waste treatment is denominated an "essential" local governmental function. Illinois $v$. City of Milwaukee, ${ }^{159}$ New Jersey v. New York City, ${ }^{160}$ Missouri v. Illinois, ${ }^{101}$ and Sanitary District of Chicago $v$. United States ${ }^{102}$ are all strong authority for the power of the federal judiciary to abate water pollution spillovers through imposition of coercive remedies on state authorities. For reasons already canvassed, the constitutional authority of Congress should be no less.

What of the moral justifications for federal controls? The health hazards from municipal waste discharges are not sufficiently grave in most cases to provide a powerful case for federal conscription of state resources to protect vulnerable local minorities. ${ }^{103}$ The moral justifications for federal coercion relate more to the potential longrun effects of insufficiently controlled water pollution in a growing society: the progressive, and perhaps inevitable, despoliation of unique natural amenities and species and the resulting impoverishment of future generations. Against these concerns stand the moral claims of state autonomy, augmented by the large, often regressively distributed financial burdens entailed by a federally coerced cleanup. Congress has sidestepped this confrontation by providing federal funding for $75 \%$ of the capital costs of the projects required to meet FWPCA. ${ }^{104}$ This

158. See S. Oster, The Incidence of Local Water Pollution Abatement Expenditures: A Case Study of the Merrimack River Basin (1974) (unpublished Ph.D. thesis in Widener Library, Harvard University). Oster found that the poor and less-educated valued water quality less than the wealthy and better educated, and also determined that municipalities in which the most recent mayoral contest was close (and in which the mayor was accordingly quite sensitive to local preferences) tended to expend significantly less on waste treatment. The regressive incidence of water pollution controls is also discussed in Council on ENVIronmental QualtTy, Exvironmental Quality 101.03 (1973). For sustained criticism of the asserted justification for the current generation of federal water pollution control requirements, see UNCERTAIN SEsRCH, supra note 91.

159. 406 U.S. 91 (1972).

160. 283 U.S. $473(1931)$.

161. 180 U.S. 208 (1901).

162. 266 U.S. 405 (1925).

163. See Uxcertain SEArch, supra note 91, at 25. Health hazards from municipal waste discharges can be avoided by prohibiting swimming in polluted waters and treating water prior to human consumption of it. $I d$.

164. See 33 U.S.C. $\$ 1282$ (a) (Supp. V 1975). There have, however, been serious delays in implementing the federal funding program. See 1976 CEQ REPORT, supra note 7, at 17-20. The program also introduces an economically inefficient capital-intensive bias in municipal waste treatment programs. 
generous financing eases local opposition by using fiscal mechanisms that mask the burden involved, distribute that burden in a less regressive fashion, and ensure the support of construction interests and local officials who can hail the economic stimulus provided without bearing the political onus of paying for it. The contest between competing national and state moral claims has been largely mooted.165

\section{Transportation Controls}

Requiring state implementation of federally drafted transportation control plans that require localities to restrict automobile use or develop mass transit alternatives presents a far more difficult case than either of the preceding examples.

Both historical practice and institutional necessity define management of local streets and highways as an "essential" local governmental function. Transaction costs normally make it infeasible to impose charges on automobiles for use of particular local thoroughfares; the expense of constructing and maintaining such roadways must ordinarily be financed through taxation. In the case of municipal power production or even municipal waste treatment, it would be theoretically possible for a local government to escape federal controls altogether by transferring its facilities to a private firm or by imposing user charges to cover the necessary costs. Because these alternatives are not feasible in the case of local highways, the fiscal burden of federal controls must inevitably fall on local and state governments and their taxpayers.

The magnitude of the resulting expenditures, including the costs of special traffic and parking controls, highway design, and mass transit facilities, would vary widely but could be quite substantial. While probably not approaching the expense of municipal waste treatment, in some locations the aggregate fiscal burden on local governments and their taxpayers of federal transportation control measures could be expected (absent compensating federal grants) to equal or exceed that imposed by the federal wage and hour measures invalidated in

165. But see Note, supra note 11, at 770 n.169 (building municipal treatment works may place substantial burdens on smaller communities).

However, the courts have recently held that municipalities must install waste treatment. controls to meet 1972 FWPCA requirements even if federal waste treatment grants have been delayed or are otherwise unavailable. E.g., State Water Pollution Control Bd. v. Train, 6 ENvir. L. REP. (ELI) 20243 (E.D. Va. Feb. 9, 1976), appeal docketed, No. 761320 (4th Cir. Mar. 19, 1976). Such decisions raise the prospect of federal enforcement actions against local officials for failure to control municipal wastes. 
NLC. ${ }^{166}$ Moreover, parking and access fees and restraints on automobile use would impose substantial social and financial costs directly upon local citizens. Such costs would generate intense political pressures on state and local officials to ease transportation controls, but these officials would be powerless to respond without incurring potent federal sanctions. Accordingly, federally mandated state implementation of transportation controls would seriously compromise local autonomy by disrupting local mechanisms of political accountability.

In addition, this federal intrusion on local government could be regarded as unwarranted because unnecessary. The federal government has ample constitutional authority to control local automobile pollution by imposing controls directly upon the drivers themselves, eliminating the need for conscription of state governments.

The potential alternative of direct federal enforcement against private actors does not, however, serve to distinguish the case of pollution by private automobiles using state-owned highways from the power plant and municipal waste treatment cases. In the latter cases the pollution generated is also attributable to the activities of private individuals (users of electricity and sewer facilities) and could in theory be eliminated by federal controls directed at such individuals. In all three cases, it would be inordinately expensive and cumbersome to create a national police force to impose federal measures on individual drivers, electricity consumers, and sewage facility users. Direct federal enforcement would also generate constant frictions with local authorities that might be far more destructive of state autonomy than mandating abatement measures by state officials.

But the cumbersome and intrusive character of direct federal controls also provides ammunition for opponents of federal coercion of

166. The net fiscal burdens incurred by the states in enforcing federal transportation controls are difficult to estimate. Insofar as a state is required to expand mass transit facilities, substantial capital and operating costs are involved. For example, in District of Columbia v. Train, 521 F.2d 971, 979, 994 (D.C. Cir. 1975), vacated and remanded per curiam sub nom. EPA v. Brown, $97 \mathrm{~S}$. Ct. 1635 (1977), the court upheld an EPA requirement that 475 buses be added to public transportation systems. Similarly the EPA estimated in 1974 that the State of California would have to purchase over 19,000 buses to meet the 1977 air quality deadlines. EPA, Transporation Controls to Reduce Automobile Use AND Improve AIR Quality in Cities 15 (1974). California maintained that restructuring the Los Angeles highway system in accordance with the federal directives at issue in the EPA $v$. Brown litigation would have cost approximately $\$ 30$ million. Brief for Petitioners at 42, Brown v. EPA, 521 F.2d 827 (9th Cir. 1975), vacated and remanded, 97 S. Ct. 1635 (1977).

Such costs might be offset to some extent by federal grants under existing mass transit and highway programs. The enforcement costs of vehicle inspection and maintenance programs could presumably be covered by inspection fees, although this would constitute forced taxation attributable to federal requirements. 
the states. Because they would be so unwieldy and expensive, direct federal controls would probably never be voted by Congress. Since direct regulation is not a viable possibility, federal coercion of state officials to carry out transportation controls cannot realistically be justified as the less burdensome alternative. Public opposition to these measures can be understood as a further "political safeguard of federalism" which Congress should not be permitted to circumvent by saddling local officials with responsibility for implementing programs for which Congress should be directly responsible, and which Congress would not enact if it bore that responsibility. On this analysis, mandating state enforcement of national environmental policies is doubly objectionable: not only does it undermine mechanisms of local political accountability by coercing state officials to impose locally unpopular measures, but it also weakens the political accountability of federal officials by deflecting to state and local governments much of the onus for federal initiatives.

These powerful objections to federally compelled enforcement of transportation controls are not outweighed by justifications for federal intervention based on considerations of local welfare. The double impairment of state and national mechanisms of accountability makes it unlikely that locally opposed national policies would better serve the preferences of local citizens than state and local policies. The most plausible case for federal intervention on intrastate welfare grounds would be that local citizens are profoundly ignorant of the adverse health effects of pollution and would, if knowledgeable, elect the federally mandated measures. ${ }^{167}$ But there are alternatives for dealing with the problem of ignorance-including intensified federal dissemination of information-that are far less destructive of state autonomy.

The existence of substantial spillover effects would, however, justify coercing state enforcement of federal measures even in the transportation control case, for the reasons previously adduced. Where, as here, the harm imposed upon sister states is attributable to pollution emanating from a state's own facilities, the offending state should not be able to escape liability to federal corrective measures by asserting claims to state autonomy that would implicitly deny the autonomy

167. It is conceivable that even a knowledgeable citizenry might be unable to secure adoption by its local government of measures promising a net increment to intrastate welfare due to the disparate influence wielded by polluters on the state level. Yet as $N L C$ itself bears witness, state autonomy values will defeat a commerce power exercise with no further claim to legitimacy than its impact on the welfare of the affionted state's inhabitants. 
of sister states. The transportation control case is not distinguishable in this respect from the municipal waste treatment case or the principle reflected in Illinois $v$. City of Milwauke $e^{\mathbf{1 6 8}}$ and earlier decisions upholding federal authority to prevent interstate spillovers generated by state-owned facilities. The state's complicity in these spillovers is manifest: polluting vehicles use state-built roadways subject to plenary state control. ${ }^{169}$ Nor may a polluter state escape federal controls by pointing to the theoretical possibility of a federal remedy running directly against its citizens. For the very claims of state autonomy which underlie $N L C$ dictate accountability qua state when harms emanating from state facilities invade the autonomy of sister states. A state cannot legitimately claim complete immunity in advancing its citizens' welfare through means that significantly burden other states' capacity to advance the welfare of their citizens. ${ }^{170}$

May the federal government requisition state enforcement of transportation control objectives in order to achieve moral ideals? The question has importance in cases where the quantum of interstate effects is not sufficient to sustain federal impositions on the spillover

168. 406 U.S. 91 (1972).

169. It is appropriate that an owner take control measures reasonably necessary to abate the pollution attributable to his facilities. In this connection, it is difficult to understand why District of Columbia v. Train, 521 F.2d 971 (D.C. Cir. 1975), vacated and remanded sub nom. EPA v. Brown, 97 S. Ct. 1635 (1977), concluded that a state could constitutionally be required to augment state-owned bus services on state highways, alter the traffic patterns on such highways, and exclude cars that were not certified as conforming to federal emission control requirements, but that it could not be compelled to inspect and test such cars to determine their conformity.

The court attempted to distinguish federal controls directed at the state highway transportation system itself, which it reasoned to be constitutional by analogy to the state-owned railroad subjected to federal controls in United States v. California, 297 U.S. 175 (1936), and federal controls requiring state regulation of private pollution sources, which it found to be unconstitutional. 521 F.2d at 990-93. But it is difficult to credit this distinction in light of the court's apparent concession that the state has an overriding obligation to control emissions from its highways. In the absence of a showing by the state that alternative measures are adequate, the federal government should not be precluded from requiring states to take such steps as are reasonably necessary to meet this obligation, including supervision of those utilizing state facilities. Could not federal railroad safety legislation require states to exclude intoxicated crewman or passengers? So long as the state's role is a substantial one (as it clearly is in the highway situation), the state should not be permitted to disclaim responsibility where its facilities invite and facilitate pollution by otherwise private actors. Cf. 40 C.F.R. $\$ 128.131$ (1976) (EPA pretreatment regulations prohibiting municipal waste treatment facilities from processing industrial wastes that do not satisfy federal pretreatment requirements).

170. As developed further in the concluding section of this article, see pp. 1267-68 infra, a state's protection of its citizens' health and welfare through land use regulation and other environmental controls should be regarded as one of the "integral" functions of local government that are protected by federalism limitations on national power. This function is impaired when a neighboring state's highways or sewers inflict substantial spillovers; the interference is not alleviated by its origin in an integral function of the neighbor. 
rationale. The moral ideals at stake are weighty: in particular, the protection of the aged, the young, and the sick (generally politically underrepresented) and the evolution of an environmentally healthier society. But mandatory transportation controls would seriously intrude upon local autonomy by imposing appreciable fiscal burdens on state and local governments, undermining mechanisms of political accountability at the local level, and deflecting important political safeguards of federalism at the national level. Moreover, as discussed earlier, transportation controls are likely to be viewed as pyramids of sacrifice by local motorists, downtown merchants, and developers. Resolution of these competing claims is postponed to the final section of this article, following examination of conditional funding alternatives and the likely extent to which any such coercive federal authority would actually be exercised.

\section{Mandating State Regulation of Privale Pollution}

Pollution from privately owned sources (such as an industrial firm) that do not utilize any state-owned facilities to produce or discharge the pollution presents the most difficult case for sustaining federally mandated controls. The state itself is not the polluter; it is being required to exercise its law-making and regulatory powers against private activities of its own citizens. Although there are several potential grounds for sustaining Congress's power to require such action, only one has persuasive force, and it is limited to cases where private pollution has significant spillover effects.

\section{a. The Preemption Rationale}

A wealth of precedent attests to the authority of the federal courts and Congress to invalidate or preempt state regulation and taxation of private activity that affects interstate commerce. ${ }^{171}$ If Congress can displace state regulation, may it not equally require it? $N L C$ does not, at first glance, appear to stand in the way, since state environmental regulation of private activity was not included in the protected core of local activities specified in that decision.

However, the displacement of both local and national mechanisms of political accountability is more sweeping and more serious where local officials are forced to extend controls on discharges from public

171. E.g., Burbank v. Lockheed Air Terminal, Inc., 411 U.S. 624 (1973) (congressional preemption of municipal regulation of aircraft noise); Michigan-Wisconsin Pipe Line Co. v. Calvert, 347 U.S. 157 (1954) (tax on gathering gas held an unconstitutional tax on interstate commerce). 
facilities to include private pollution as well. Interference with the states' political autonomy and the associated threat to self-determination values are likewise greater when the state is required affirmatively to regulate private pollution than where such regulation is preempted. Diseconomies of scale and political opposition to creation of massive federal enforcement bureaucracies make it unlikely that widespread preemption of state control would produce a parallel increase in federal control. By contrast, requiring the states to enforce federal measures against private pollution circumvents the political safeguards of federalism provided by these obstacles to direct federal enforcement.

The presence of interstate spillovers would not of itself present a sufficient counterweight to these considerations, since here the spillovers do not represent infringements on sister state autonomy by direct action of the state to be regulated. The moral calculus is likewise weighted against federal power. In comparison to pollution from public facilities, federal marshalling of state regulatory mechanisms to curb private sources would constitute a more far-reaching interference with state autonomy, while the state's responsibility for the pollution is more attenuated.

Thus the commerce clause should not be read as granting general federal authority to mandate state regulation of private pollution sources. ${ }^{172}$ This conclusion rests on a public/private distinction that is conceptually vulnerable. ${ }^{173}$ After all, it is state laws and regulations which create and define private property rights, including the right to pollute; logically, all pollution might be attributable to states. However, as with the concept of "state action" under the Fourteenth Amendment, ${ }^{174}$ an imperfect distinction between public measures and private activity may be pragmatically necessary to secure an effective limitation on national power.

\section{b. The "Necessary and Proper" Clause}

The necessary and proper clause affords an equally sweeping rationale for federal conscription of state regulatory powers over private citizens. Given Congress's commerce power to control private pollution directly, and given also the costs and cumbersome nature of di-

172. While the commerce clause will not underwrite such authority, there may be other bases for federal power in the private polluter context. See pp. 1248-49 infra.

173. See Michelman, supra note 146, at 1168-69.

174. See generally G. Gunther, Cases and Materials on Individual Rights in ConSTITUTIONAL LAw 504-59 (2d ed. 1976). 
rect federal controls, may not Congress require state enforcement of such controls as a necessary and proper means to a concededly legitimate end? ${ }^{150}$ This line of argument is subject to all the objections just mounted against the preemption rationale. The necessary and proper construct simply makes more explicit the fundamental objection to a general power of federal conscription-the reduction of the states to federal appendages and the circumvention of the political safeguards of federalism.

\section{c. The Fourteenth Amendment}

If the substantive interest in environmental quality were protected by constitutional due process, Congress might require state enforcement of federal measures under its power to enforce the Fourteenth Amendment by "appropriate legislation." ${ }^{176}$ Given the history of judicial deference to Congress's exercise of this power, state property and tort law might implicate the states in private pollution to an extent sufficient to support invocation of the Fourteenth Amendment. ${ }^{177}$ Moreover, federalism principles do not limit Congress's exercise, at least on the scale contemplated here, of its Fourteenth Amendment powers to secure citizens' rights from state interference. ${ }^{178}$

175. The necessary and proper rationale has been advanced by proponents of national "no-fault" legislation that requires state officials to implement federal automobile insurance programs if the state's program does not meet federal standards. For discussion of the constitutional issues presented, see Dorsen, The National No-Fault Motor Vehicle Insurance Act: A Problem in Federalism, 49 N.Y.U. L. Rev. 45 (1974); Note, Is Federalism Dead? Constitutional Analysis of the Federal No-Fault Automobile Insurance Bill: S.35t, 12 HaRv. J. Legis. 668 (1975).

176. U.S. Cosst. amend XIV, § 5: "The Congress shall have power to enforce, by appropriate legislation, the provisions of this article."

177. For a discussion indirectly supporting Congress's $\$ 5$ power to expand judgemade notions of "state action," see Cohen, Congressional Power to Interpret Due Process and Equal Protection, 24 Stan. L. Rev. 603 (1975).

178. Compare National League of Cities v. Usery, 426 U.S. 833 (1976) with Fitzpatrick v. Bitzer, 427 U.S. 445 (1976) (sustaining Congress's constitutional power to authorize private damage actions against state officials for sex discrimination in employment). In his opinion for the Court in Fitzpatrick, Justice Rehnquist placed great emphasis on the circumstance that the statute in question was based on Congress's $\$ 5$ power. $I d$. at 452 56. He argued that because the Fourteenth Amendment was adopted with the avowed purpose of limiting state autonomy, constitutional principles of federalism do not limit Congress's power to invade state autonomy as severely when it legislates under $\$ 5$ as when its enactment is based on the commerce power. Id. Despite earlier learning that Congress's power to adopt remedial legislation under the Fourteenth and Fifteenth Amendments is to be tested by the same standard applied in cases construing the necessary and proper clause, see Katzenbach v. Morgan, 384 U.S. 641, 650-51 (1966), there is persuasive force to Justice Rehnquist's distinction once the principle of federalism limitations on national powers is conceded. Lacking explicit statement in the Constitution, that principle must take at least some of its content from historical analogy; and the adoption of the Fourteenth Amendment did contemplate incursions on state autonomy that were not envisioned at the original adoption of the Constitution. 
But this entire line of argument rests on a false premise. It is simply not plausible (for reasons developed elsewhere by the author ${ }^{179}$ ) that due process secures a right to environmental quality. However broad Congress's discretion in enforcing the Fourteenth Amendment, it does not extend to the creation of wholly novel constitutional rights. Such a prerogative would permit easy circumvention of federalism limits on national power. ${ }^{180}$

\section{d. The Testa v. Katt Rationale}

Testa $v$. Katt determined that Congress could require state courts to entertain lawsuits based on federal law when they heard similar state-law cases. ${ }^{181}$ Where states are engaged in regulating private pollution through a combination of state-law administrative and judicial remedies, the logic of Testa $v$. Katt might support a congressional requirement that states also enforce federal regulations. This argument presents two related difficulties: whether the principle of Testa $v$. Katt applies to state administrative measures; and, even if it does, whether states may properly decline to enforce federal requirements on the ground that they are unduly burdensome.

Article III of the Constitution is instinct with the expectation that state courts would entertain cases based on federal law. ${ }^{182}$ Enforcement of federal requirements through state administrative measures lacks this historically based constitutional dimension. But regulatory agencies are often created to displace or supplement judicial

179. See Stewart, supra note 17 , at 714-15, 754-56.

180. Whatever the limits of Congress's $\$ 5$ power to alter the content of judicially recognized Fourteenth Amendment rights, see generally G. Gunther, Cases Axd Materials on Constitutional Law 998-1039 (9th ed. 1975), it surely does not include the powcr to accord constitutional status to wholly novel categories of interests.

However, Professors Michelman and Tribe have argued that $N L C$ implies a right on the part of local citizens to receive certain basic services from state and local governments, a right that might be enforceable through congressional legislation under the Fourteenth Amendment. See Michelman, supra note 146, at 1181-91; Tribe, Unraveling National League of Cities: The New Federalism and Affirmative Rights to Essential Government Services, 90 Harv. L. REv. 1065, 1076-77 (1977). If this analysis were accepted, it might be difficult to exclude the interest in preservation of environmental quality from the class of protected citizen rights that could be congressionally enforced. See p. 1267 infra.

181. 330 U.S. 386 (1947). The Court held that Rhode Island state courts could not decline to entertain a private action, authorized by federal statute, for recovery of treble damages and litigation expenses against a private defendant who had assertedly violated federal price ceiling regulations. Although the Rhode Island courts entertained similar claims based on Rhode Island law and otherwise had jurisdiction to hear the case, they declined to do so on the ground that the federal remedy was "penal" in character. $I d$. at 388.

182. See HART \& WEChSLER, supra note 116 , at $11-12$. 
remedies that have proven inadequate. ${ }^{183}$ Accordingly, the principle of Testa $v$. Katt should probably track the transfer from courts to administrative agencies of responsibility for controlling environmental degradation.

Even so, Testa $v$. Katt itself arguably did no more than prohibit state discrimination against federal law as such in an instance where there was no substantial and legitimate state interest in declining to enforce federal law. State implementation of federal pollution control requirements could involve significant burdens of two sorts. First, there are the substantial costs to the state of implementing federal requirements, such as transportation controls, ${ }^{184}$ that are more far-reaching or rigorous than comparable state controls. Second, the impairment of local political mechanisms involved in requiring state administrative officials to enforce locally unpopular federal measures may be greater than when state judges are required to apply federal law. Judges, in resolving individual controversies, are expected to promote the impartial application of the law and to remain substantially insulated from local political sentiment. But underpinning the establishment of many administrative agencies was a belief that judicial remedies were inadequate, and a desire to make the development and implementation of governmental policy more politically responsive. ${ }^{185}$ Application of the Testa $v$. Katt principle to require administrative implementation of locally unpopular measures would therefore represent a more serious invasion of legitimate state autonomy claims than does its application to state courts. Some federal requirements-such as those involved in proposed federal "no-fault" legislation ${ }^{186}$-imposing de minimis burdens (whether fiscal or political) on state officials might be sustained on a Testa $v$. Katt rationale. Transportation controls and other burdensome federal environmental requirements probably cannot.

\section{e. The Reverse Parens Patriae Principle}

The discussion thus far has failed to generate a source of congressional power to compel states to rein in their private polluters, regardless of the magnitude of injury which those actors may inflict

183. For a review of the limitations upon judicial remedies for environmental degradation, see J. KRIER, supra note 78, at 208-33.

184. See note 166 supra.

185. This view, for example, played a major role in the creation of state railroad commissions in the nineteenth century. See Clark, State Railroad Commissions and How They May Be Made Effective, 6 Publications of the Am. Econ. Ass'n 473, 493-512 (1891).

186. See note 175 supra. 
upon neighboring states. Yet it remains troublesome that the availability of an effective remedy should hinge on whether the invasion is "public" or "private" in origin. It is no answer to point to the possibility of suing the private sources individually, for that is an invitation to what will frequently be multiplicitous litigation of little utility. ${ }^{187}$

An avenue of escape from this difficulty is suggested by the fact that the very state which seeks to stand aloof from the depradations of its citizens and industries is able to obtain a remedy on their behalf, as parens patriae, for injuries caused by pollution from neighboring states. ${ }^{188}$ In so doing, the state identifies the welfare of its citizens with its own and affords a vehicle for surmounting the inadequacy of individual citizen remedies. These principles justify imposition of liability on the same basis against a state defendant. Since states can obtain an award of relief for pollution-related injuries suffered by their citizens, they should be reciprocally liable for comparable damage attributable to their citizens. Accordingly, injured states should be permitted to invoke a reverse parens patriae principle by requiring an originating state to control private sources of spillover pollution.

This logic would empower federal courts, in litigation between states, to commandeer state regulatory powers over private pollution sources. Congress should possess a similar prerogative. It should be allowed to act as a surrogate for threatened states and preserve the system of union by taking prophylactic measures to eliminate spillovers that might otherwise provoke costly suits and conflict between the states. ${ }^{189}$ Congress could accordingly require states to impose controls on private sources that generate pollution spillovers sufficiently serious to occasion judicial relief in litigation between states. ${ }^{100}$

187. See Missouri v. Illinois, 180 U.S. 208, 241 (1901) (sustaining Missouri's standing parens patriae to protect its citizens against interstate pollution on the ground that "suits brought by individuals . . . would be wholly inadequate").

188. See Georgia v. Tennessec Copper Co., 206 U.S. 230 (1907); Missouri v. Illinois, 180 U.S. 208 (1901).

189. See note 129 supra; Missouri v. Illinois, 180 U.S. 208, 241 (1901) ("If Missouri were an independent and sovereign state all must admit that she could seek a remedy by negotiation, and, that failing, by force. Diplomatic powers and the right to make war having been surrendered to the general government, it was to be expected that upon the latter would be devolved the duty of providing a remedy . . . ."); C. WarRen, THE Supreme Court AND THe Sovereign States 38 (1924) (citing examples of heated disputes between states resulting in armed conflict before litigation was undertaken).

190. See note 129 supra. But NLC considerations would bar such initiatives where congressional action was justified only by concern with the welfare of the state in which the pollution originates. And moral considerations are insufficient bases for federal action in the private polluter case for reasons discussed above.

191. See p. 1240 supra. 
It may be objected that the courts' power to mandate state control of private pollution sources under a reverse parens patriae principle does not entail a like power in the Congress, because Congress could impose a system of federal controls on private sources, an alternative less destructive of state autonomy. ${ }^{191}$ However, as already noted, ${ }^{192}$ a system of federal controls on small pollution sources such as automobiles or private dwellings would require the creation of an enormous federal police force discharging functions that would overlap and often conflict with those performed by state and local officials. Creation of such a police force would itself represent a grave threat to local autonomy. ${ }^{103}$ Of course, the fiscal and political costs of this alternative are so great that it would never be undertaken. But these costs should not bar Congress from providing states injured by spillovers with an effective remedy. Just as the courts would be justified in awarding or imposing parens patriae liability because suits by or against individual polluters are too cumbersome and expensive to serve as a realistic alternative, so Congress should be able to impose similar parens patriae liability on states to control private sources of pollution where a system of direct federal controls is similarly impractical. ${ }^{194}$

\section{Summary}

The burden of this lengthy discussion can be briefly summarized. There are constitutional limitations on Congress's power to mandate state implementation of federal environmental policies. Assuming these limitations to be justiciable, they do not preclude Congress from requiring states to abate pollution from state-owned power plants, waste treatment plants, or other public facilities, where such pollution causes substantial adverse effects in neighboring states. In order to deal on a prophylactic basis with interstate disputes and provide an effective remedy for states threatened by spillovers, Congress may also require a state to control spillover pollution from private sources within the state. Where, however, the only colorable justification for

192. See id.

193. See Pennsylvania v. EPA, 500 F.2d 246, 262-63 (3d Cir. 1974) (upholding federal authority to conscript state regulatory powers, and observing with respect to alternative of direct federal regulation that "we fail to see how this would represent less of an intrusion upon state sovereignty").

194. This analysis would limit federal compulsion of the states to cases, such as pollution by automobiles in use, where a system of direct federal controls was not a reasonably feasible alternative and might not support a federal requirement that states control large industrial pollution sources. 
congressionally mandated controls is to promote the welfare of the polluting state's population, state officials may not be required to implement them if the pollution originates from private sources or if it originates from public sources (such as local highways) whose control would substantially burden local services deemed "integral" in $N L C .{ }^{195}$ Where federal aims are justified by national moral ideals, such as protection of vulnerable minorities or the interests of future generations, Congress lacks power to mandate state regulation of private pollution sources. But where Congress seeks to curb state sources of pollution on moral grounds, the claims of national power and state autonomy are most nearly in equipose. The resolution of these claims, and of the overriding question of justiciability, is postponed to the final section.

\section{Limitations on Federal Power to Induce State Implementation of Environmental Policies Through Conditional Grants}

Would imposition of conditions on federal grants to state and local governments represent a superior alternative to compulsory directives for promoting implementation of federal environmental policies? The courts of appeals which denied EPA statutory authority to coerce promulgation of transportation controls by state officials pointedly suggested that it would. ${ }^{196}$ This suggestion was followed up by Congress in the 1977 Clean Air Act Amendments, which call for termination of Clean Air Act grants in regions that fail to implement SIPs or meet modified TCP requirements, and also provide for termination by the Secretary of Transportation of highway and other transportation grants in regions failing to meet TCP requirements. ${ }^{197}$ It may be that

195. The analysis developed in this section suggests that the federal measures struck down in $N L C$ because they impaired "integral" state and local functions might have been sustained under special "spillover" or "moral sacrifice" justifications for fcderal intervention. For example, federal minimum wage and maximum hour provisions could be understood as measures to deal with spillover problems created by the reluctance of a state to raise taxes in order to pay higher wages for public employees; the state might fear that industry or wealthy taxpayers might move to states with lower wages and lower taxes. However, there was no concrete evidence in $N L C$ of serious spillover effects. Conceivably the same measures could be understood as advancing moral goals such as the eradication of "wage gouging" or the amelioration of poverty, although, for reasons outlined by Justice Stevens in his dissent, see 426 U.S. at 881 , such justifications scem unpersuasive in this case.

196. See Maryland v. EPA, 530 F.2d 215, 228 (4th Cir. 1975), vacaled and remanded per curiam sub nom. EPA v. Brown, 97 S. Ct. 1635 (1977); District of Columbia v. Train, 521 F.2d 971, 993 n.26 (1975), vacated and remanded per curiam sub nom. EPA v. Brown, 97 S. Ct. 1635 (1977).

197. See note 53 supra. 
threatened withdrawal of the "carrot" of federal funds will prove more efficacious than the threatened "stick" of criminal and civil sanctions. Moreover, while the NLC holding restricts Congress's power under the commerce clause to compel state action, the opinion leaves open the possibility that Congress's use of the spending power to accomplish the same result would not be subject to comparable constitutional restrictions. ${ }^{108}$

Nonetheless, the conditional spending power has both practical and constitutional limitations that make it an unsatisfactory alternative to the more direct power of the federal government, under the commerce power or the power to resolve interstate disputes, to require state officials to implement environmental controls. Threats to terminate federal grants typically have little credibility and at best modest efficacy in promoting compliance with federal program standards. ${ }^{199}$ EPA officials responsible for disbursing Clean Air Act grants would be reluctant to cut off the life blood of their own programs. ${ }^{200}$ Even if this barrier could be surmounted, threatened federal refusals to fund state air pollution control programs would often be ineffectual in securing local enforcement of automobile controls since the political and economic costs of such enforcement would frequently be more than the costs of simply forgoing the federal funds. ${ }^{201}$ Termination of highway funds and other federal programs grants (such as municipal waste treatment grants or revenue sharing funds) would provide greater incentives for states to carry out federal pollution control requirements. But the Secretary of Transportation and comparable officials responsible for such programs would be most unwilling to impose grant terminations in order to assist EPA air pollution control

198. See 426 U.S. at 852 n.l7 ("We express no view as to whether different results might obtain if Congress seeks to affect integral operations of state governments [through the spending power].")

199. See Tomlinson \& Mashaw, The Enforcement of Federal Standards in Grant-inAid Programs: Suggestions for Beneficiary Involvement, 58 VA. L. REv. 600, 619-29 (1972).

200. Because of the political and administrative resistance to terminating federal grants for violation of grant conditions, fcderal officials have sometimes resorted to litigation, seeking a judicial order requiring recipient compliance. E.g., United States v. San Francisco, 310 U.S. 16 (1940) (land grant with conditions); United States v. Fraser, 297 F. Supp. 319 (M.D. Ala. 1968), enforced, 317 F. Supp. 1079 (1970). Judicial enforcement of grant conditions has also been obtained by private third party beneficiaries of grant programs. 'Townsend $v_{3}$ Swank, 404 U.S. 282 (1971); California Dep't of Human Resources Dev. v. Java, 402 U.S. 121 (1971); Rosado v. Wyman, 392 U.S. 397, 420-21 (1970). See Tomlinson \& Mashaw, supra note 199, at 630.37.

201. This fact may render judicial enforcement of grant conditions, see note 200 supra, of little avail unless a state that is unwilling to meet these conditions can be threatened with the loss of federal grants other than those upon which the conditions are imposed. 
efforts. Moreover, it will be argued below that such terminations would in many instances be invalid because they would exceed the limits of Congress's spending power or violate the federalism principles recognized in NLC.

To set the stage for a discussion of these constitutional issues, some elementary ground rules must be set forth. All would concede that exercises of federal power must be authorized by some explicit or implicit grant of authority in the Constitution. This requirement should apply as fully to the imposition of conditions on receipt of federal funds as to their disbursement. ${ }^{202}$ Accordingly, conditions on federal grants must either bear a rational relation (via the necessary and proper clause) to the Congress's constitutional power to levy taxes and spend revenues for the general welfare (the power that supports the federal grant itself) or such conditions must be necessary and proper clause) to Congress's constitutional authority to levy prerogative. ${ }^{203}$ Otherwise, the Constitution's limited grant of federal powers could be exceeded by conditioning the receipt of federal bounty upon acquiescence in measures not independently supportable as permissible goals of federal legislation. Furthermore, grant conditions may not contravene any of the constitutional prohibitions that limit the exercise of all federal powers. ${ }^{204}$

With these general principles in mind, we can undertake an analysis of the constitutional limits of the spending power. To make the discussion more concrete, we will consider the power of Congress to terminate federal grants to states that fail or refuse to implement transportation control measures. ${ }^{205}$

202. See Note, Unconstitutional Conditions, 73 HARv. L. Rev. 1595, 1599-1602 (1960).

203. For example, the federal government might terminate grants to a state or person as a sanction for failure to observe requirements validly imposed under the commerce power.

204. See O'Neil, Unconstitutional Conditions: Welfare Benefits with Strings Attached, 54 CALIF. L. REv. 443, 463 (1966); Wilcox, Invasions of the First Amendment Through Conditioned Public Spending, 41 CoRnell L.Q. 12 (1955).

205. The discussion which follows assumes, for present purposes, the justiciability of the issues presented. Grant conditions contravening express constitutional prohibitions are justiciable. See, e.g., Sherbert v. Verner, 374 U.S. 398 (1963). It is far more doubtful whether particular instances of federal spending would be invalidated as falling outside Congress's authority to spend for the "general welfare" in view of the broad judicial deference to Congress's judgment on the question. See Helvering v. Davis, 301 U.S. 619, 640-41 (1937). Conditions on recipient activities unrelated to the object of the grant should, however, be subject to court challenge in order to prevent potentially farreaching extensions of federal power beyond the constitutional grant. Cf. The Employers' Liability Cases, 207 U.S. 463, 502 (1908) (invalidating use of the commerce power to regulate unrelated intrastate activities). Whether spending conditions should be subject to judicial invalidation as invasions of constitutionally protected state sovereignty is discussed in the conclusion. See p. 126 infra.

Distinct from the issue of justiciability is that of standing. A state that has accepted 


\section{A. Termination of Grants for Direct Expenses of Implementing Transportation Controls}

Where the federal government seeks to terminate the grants that cover the direct expenses to state governments of imposing the transportation controls themselves, the problem seems trivially easy. If a state fails to conform to federal requirements for state transportation control programs, may it not be deprived of federal funds appropriated for the support of such programs? Yet $N L C$ potentially raises two constitutional objections to imposing such a condition on the expenditure of federal grants.

First, if federalism limitations preclude coercive use of the commerce power to force state implementation of federal controls, then conditions on federal grants requiring such implementation are (it may be argued) likewise invalid because they seek to accomplish the prohibited result indirectly, by "buying up" the states' rights to be free of coercive controls. However, this objection is not sound if (as here) the conditions on state use of federal funds are reasonably calculated to advance the general welfare objective of the disbursement itself. The spending power is an independent grant of constitutional authority, ${ }^{200}$ and it is not a valid objection to an otherwise proper exercise of that power that it accomplishes a result that could not constitutionally be achieved through the exercise of federal powers other than the spending power.

conditioned funds may challenge those conditions when funds are withdrawn or other sanctions imposed for their violation. Oklahoma v. United States Civil Service Comm'n, 390 U.S. 127, 134-42 (1947); Ohio v. United States Civil Service Comm'n, 65 F. Supp. 776, 781 (S.D. Ohio 1946). But Massachusetts v. Mellon, 262 U.S. 447, 480.83 (1923), held that Massachusetts could not complain of assertedly unconstitutional conditions on federal funds that it had not accepted on the ground that no rights of the state had been invaded by the rejected federal offer. The decision seems to reflect the now discredited notion that government grants made under statutory directives are "privileges," and is probably not good law today in light of decisions such as Oklahoma v. United States Civil Service Comm'n, supra (cmphasizing Oklahoma's statutory entitlement to the funds whose conditions were challenged), and Sherbert v. Verner, supra (according standing to a potential recipient denied funds because of her refusal to accept the associated conditions). If a state is otherwise entitled to receive federal funds, it should be able to challenge the validity of conditions attached to the funds without being forced to accept them (and be subject to enforcement of the conditions if their validity is upheld). Cf. Abbott Laboratories v. Gardner, 387 U.S. 136 (1967) (relaxing ripeness doctrines to permit preenforcement challenge of federal agency regulations).

206. In United States v. Butler, 297 U.S. I (1936), the Supreme Court rejected the theory advanced by Madison that the taxing and spending powers were restricted in scope to the specific legislative fields enumerated in Art. I, $\S 8(e . g$., maintenance of post roads). It adopted instead the so-called "Hamiltonian" view that "Congress ... has a substantive power to tax and to appropriate, limited only by the requirement that it shall be exercised to provide for the general welfare of the United States." 297 U.S. at $65 \cdot 66$. 
But NLC introduces a second, more troubling, possibility. If constitutional principles of federalism delineate a zone of state autonomy which is presumptively protected from congressional incursions, these principles limit the federal spending power no less than the commerce power. ${ }^{207}$ The potentially impermissible intrusions on state autonomy reviewed in the previous section are of two sorts. The first are fiscal burdens (at issue in NLC itself) that drain limited state resources or force additional taxation. But so long as the only sanction for violation of federal conditions is a withdrawal of the federal funds intended for the use stated in the conditions, there appears to be no constitutionally suspect burden imposed. The state could avoid any shortfall by simply refusing the funds and declining to initiate the recommended program.

Federal conditions might also invade state autonomy by interfering with local mechanisms of political decisionmaking. This objection to grant conditions is not fully met by the fact that the state can avoid the conditions by declining the grant. The ability of industry and individuals to move among jurisdictions in order to escape high local taxes creates a fiscal "commons" dilemma for the states. ${ }^{208}$ This circumstance, together with citizens' demands for a high level of state and local services, renders states highly dependent on federal grants. Debating whether conditions on federal grants in these circumstances "coerce" the states ${ }^{209}$ is an unhelpful anthropomorphism. The structure of the federal system under current social and economic conditions makes it inevitable that states will become subject to the federal spending power, just as it makes it inevitable that they will become subject to the federal commerce power. The question in either case is not whether federal requirements overbear an hypostasized state "free will," but whether they unduly compromise a normative political conception of state autonomy.

Congress presumably imposes conditions on federal grants because

207. Cf. Sherbert v. Verner, 374 U.S. 398 (1963) (state government may not compel Seventh Day Adventist to seek work which violates her religious precepts by withholding unemployment compensation); United States v. Butler, 297 U.S. 1 (1936). The Butler opinion invalidated the Agricultural Adjustment Act, a congressional taxing and spending scheme which transferred funds exacted from farm product processors to farmers who agreed to limitations on acreage planted. The six-Justice majority characterized the Act as an effort to usurp one of the powers reserved to the states (regulating agricultural production), and observed that "the attainment of a prohibited end may not be accomplished under the pretext of the exertion of powers which are granted." Id. at 68 .

208. See note 73 supra.

209. Compare Steward Machine Co. v. Davis, 301 U.S. 548, 585-93 (1937) and Massachusetts v. Mellon, 262 U.S. 447,482 (1923) (finding of no cocicion) with United States v. Butler, 297 U.S. I, 70-72 (1936) (finding of coercion). 
state officials might otherwise spend the funds in a manner inconsistent with the conditions. Thus, any conditions on federal funds potentially interfere with local mechanisms of political accountability by preventing local officials from responding to constituent preferences whenever they might differ from those of Congress. However, federal officials are accountable to their constituencies for the disbursement of funds raised by federal taxes, and may properly insist that those funds be spent in the service of federally defined objectives. Moreover, if restrictions on expenditures of federal money per se were to constitute an impermissible interference with state autonomy, all federal conditional grants would be rendered unconstitutional. Such a startling conclusion, which would invalidate at a stroke some $\$ 46$ billion of federal spending ${ }^{210}$ and shatter the lynchpin of "cooperative federalism," is hardly acceptable.

As long as the conditions imposed are limited to the use of the funds subject to withdrawal if those conditions are violated, there appear to be only two classes of cases in which the conditions might be viewed as unconstitutionally compromising state autonomy. First, there may be cases where conditions not only restrict state officials' use of funds but also require the state to impose substantial burdens on its own citizens-for example, the 55 m.p.h. speed limit required as a condition of federal highway funds. ${ }^{211}$ Such a condition, accompanying funds which the state cannot afford to forgo, intensifies federal interference with local mechanisms of political accountability by compelling states to enforce against their constituencies restrictions that the constituencies oppose. But the fact that federal conditions on grants to state governments are calculated ultimately to shape the conduct of private citizens cannot be grounds for declaring such conditions unconstitutional without unduly narrowing the "general welfare" that defines the spending power and eviscerating large segments of existing conditional grant programs.

Second, grant conditions might be invalidated for invading state autonomy in cases where they explicitly require some specified form of political or institutional structure for state or local government. But in Oklahoma v. United States Civil Service Commission, ${ }^{212}$ the Supreme Court sustained against constitutional attack the Hatch

210. See Schultz, Federal Spending: Past, Present, and Fulue, in Setrinc National Prionirics: Tiic Nifit Ten Yeiks 323, 360 (H. Owen \& C. Schultze eds. 1976) (table 8-18; figure obtained by subtracting funds appropriated for revenuc shaxing and block grants from total sum devoted to federal grants-in-aid).

211. 23 U.S.C. $\$ 154$ (Supp. V 1975). See id. \$111 (recpuiring state certification that it is enforcing 55 m.p.h. speed limit).

212. 330 U.S. 127 (1947). 
Act's prohibition of the political activities of a state highway commissioner. The highway commissioner was subject to the Hatch Act because the state received federal highway funds. That decision suggests that conditions reasonably related to the purposes of federal spending programs will not be invalidated unless they impose quite extreme or unusual constraints on the structure of state government."113 Compliance with current federal environmental regulations does not appear to threaten any core values of institutional autonomy. ${ }^{-14}$

Thus the analysis concludes that, notwithstanding $N L C$, states that receive federal transportation control funds may constitutionally be required to implement such controls as a condition of receiving the funds. ${ }^{215}$ As already pointed out, however, ${ }^{216}$ the threatened termination of these funds alone is likely to be wholly ineffectual in securing state compliance. To promote implementation, federal authorities will have to possess additional leverage over state officials through the power to withdraw other federal funds disbursed for

213. See id. at 143 ("While the United States is not concerned with, and has no power to regulate, local political activities as such of state officials, it does have the power to fix the terms upon which its money allotments to states shall be disburscl.")

It might be argued that Oklahoma $v$. United States Civil Service Commission requires modification in light of $N L C$. The focus of $N L C$ is on fiscal burdens, but the Courts concern with such burdens stems from their capacity to compromise state political autonomy by requiring the state either to raise taxes or to restructure the delivery of "essential" governmental services. See 426 U.S. at 847 . But carying this argument too far runs the risk of invalidating all federal grant programs. See p. 1255 supra. In any event, to the extent that $N L C$ weakens Oklahoma $v$. Civil Service Commission, it lends support to the thesis of this section that conditions on federal grants do not provide a secure constitutional base for forcing states to implement federal programs.

214. For example, under $\$ 110$ of the Clean Air Act, 42 U.S.C. \$ $1 \$ 57 \mathrm{c}-5$ (1970 \& Supp. $\left.V^{\prime} 1975\right)$, the states are given an opportunity to frame their own package of control measures so long as it satisfies the overriding statutory requirement of achiering federal ambient standards. Given the absence of detailed empirical study, it is not possible to reach firm conclusions about the impact of either federal cnvironmental regulatory requirements or grant conditions on the structure and operation of state and local governments. One survey found that in order to accept delegated responsibility for administering the permit system of the National Pollution Discharge Elimination System under the 1972 FWPCA, most states found it necessary to enact enabling legislation and amend existing laws and procedures. See V. Price, supra note 8 , at 10 . Specific institutional arrangements, such as representation of industrial interests on state boards with adjudicatory responsibilities regarding environmental matters, have been restricted by federal regulation. Id. at 18. The impact of grant conditions has apparently becn more modest, although federal programs to create and fund regional water planning authorities to control nonpoint source pollution under $\$ 208$ of the 1972 FW'PCA, 33 U.S.C. \$ 1288 (Supp. V 1975), stirred opposition from state and local officials who foared that creation of these new bodies would erode their authority. V. Price, supra note 8 , at $50-51$.

215. Cf. Vermont v. Brinegar, 379 F. Supp. 606 (D. Vt. 1974) (sustaining constitutionality of requirement in Highway Beautification Act of 1965 that state remore ad. vertising signs adjacent to federally funded highways and pay just compensation to owners).

216. See p. 1251 supra. 
different purposes. But extending the cut-off sanction so broadly raises additional, interrelated problems of the general dimensions of the federal spending power and the special implications of $N L C$.

\section{B. Forcing Implementation of Transportation Controls by Placing Conditions on Grants for Other Programs}

If state implementation of national environmental policies could be mandated through the exercise of a federal power (such as the regulation of commerce) other than the spending power, then the withdrawal of any and all federal funds to a state could be employed as a sanction for a state's recalcitrance. The withdrawal would be a necessary and proper measure to ensure compliance with a legitimate exercise of congressional power. Thus, since Congress could invoke the commerce clause to require state enforcement of a reduced speed limit on public highways, ${ }^{21}$ states that balked at doing so could be denied federal funds for highway construction (or school lunches, for that matter). Accordingly, in cases where Congress has authority to mandate state initiatives under its commerce power or power to deal with interstate conflicts, all federal grants to a state could, in theory, be terminated if the state failed to carry out the federal demands. However, in cases where federal coercive authority is limited by federalism principles recognized in $N L C$, and the only relevant source of federal power to control state conduct is the imposition of conditions on a specific federal grant, it becomes necessary to explore the scope of the conditional grant authority.

Congress's power to raise taxes and spend for the general welfare is, like every other power granted the national government, a limited one. Yet the spending power would be effectively unlimited if Congress were free to condition a grant with respect to one activity on the recipient's compliance with federal requirements on other activities that the federal government has no direct constitutional power to control. Because decisional law on this question is absent, one must reason by analogy from the established law governing the

217. Quite apart from protecting the safety of interstate travellers, a congressionally mandated 55 m.p.h. specd limit would be a valid means of reducing gasolinc consumption and consequent national dependence on imported oil. If the "spillover" rationale supports federal disruption of state self-determination in order to protect sister states" capacity for self-determination, then by extension it also permits intervention in matters of national defense or foreign relations central to the Union's security. See Case r. Bowles, 327 U.S. 92 (1946) (war power authorizes Congress to impose wartime price controls on state's sale of its timber). Cf. Sanitary Dist. v. United States, 266 U.S. 405 (1925) (right of federal government to obtain injunction against Iocal diversion of Lake Michigan water justified in part by reference to treaty power). 
exercise of other federal powers. The following discussion will largely rely on examples drawn from the recognized limits on the power generally cited as a vehicle for mandating state implementation of federal programs: the commerce power.

When enacting commerce power measures applicable to a state or person engaged in both interstate and intrastate activities, the federal government may not prohibit or burden the interstate activities as a sanction for disapproved intrastate conduct. ${ }^{218}$ The intrastate activities can be federally controlled if they have material interstate effects, ${ }^{219}$ or if they form part of a congressionally designated class that includes interstate activities (or intrastate activities with interstate effects) and class treatment is an appropriate means of vindicating federal power over interstate commerce. ${ }^{220}$ But a general power to regulate a person's intrastate conduct by interfering with that same person's interstate activities is denied, because it would extend the reach of federal power beyond that granted by the Constitution.

Now suppose that a person is engaged in two sets of interstate activities, $A$ and $B$. May the federal government prohibit or burden activity $A$ as a sanction for noncompliance with federal requirements for activity $B$ ? Certainly it may do so under the necessary and proper clause where compliance with federal requirements for activity $B$ would also further federal regulatory objectives for activity $A$. Thus, violation of nationwide federal pollution control requirements for trucks would be a legitimate basis for denying noncomplying trucks the use of interstate highways in order to prevent the generation of air pollution from those highways.

But even where the requirements are not functionally related, violation of federal requirements for the $B$ activities could be grounds for prohibiting the $A$ activities. Congress may deny the benefits of interstate commerce to those who fail to comply with national moral, social, or economic policies; ${ }^{221}$ the principle that persons should obey federal requirements to which they are subject would underlie such a policy. The federal government could accordingly bar from interstate highways the trucks of a company that failed to observe federal

218. The Employers' Liability Cases, 207 U.S. 463, 502-03 (1908).

219. United States v. Darby, 312 U.S. 100 (1941).

220. Perez v: United States, 402 U.S. 146 (1971) (federal sanctions against loan sharking upheld since prohibition activity belongs to class with impact on interstate commerce); Wickard r. Filburn, 317 U.S. 111 (1942) (upholding fecleral regulation of homeconsumed wheat due to cumulative impact on interstate commerce).

221. See United States v. Darby, 312 U.S. 100, 114 (1941) (quoted in note 132 supra); Hoke v. United States, 227 U.S. 308 (1913). 
minimum wage and hour laws with respect to employees whose work was wholly unrelated to its trucking activities. However, if the firm were to eliminate the interstate aspects of its $B$ activities, failure to observe federal requirements with respect to such activities could no longer be grounds for prohibiting or burdening the $A$ activities which remain interstate. Congress may not extend its constitutional powers beyond their limited scope by manipulating legitimate objects of regulation to achieve ends it may not accomplish directly.

Applying these principles to conditional funding, it appears that the federal government may terminate funds for state activity $A$ if the state fails to comply with conditions on federal grants it receives for activity $B$. For the federal government may, by analogy to the commerce power, deny the benefits of federal funds to persons who fail to comply with national policies, and promoting compliance with restrictions on all federal funds received is such a policy. But (again by analogy to the commerce power) once a state declines funds for activity $B$, the federal government may not deny funds for activity $A$ because of the state's failure to comply with federal requirements with respect to activity $B$ unless: (1) the federal government has independent constitutional authority to regulate activity $A$, or (2) the federal requirements on activity $A$ can be justified as necessary and proper to achievement of federal objectives in spending money for activity $B$.

This latter rationale would justify termination of mass transit funding in heavily polluted cities that fail to enforce transportation controls on automobiles, because such controls would substantially advance an important objective of that funding: diversion of travelers from automobiles to mass transit. But, assuming that the state has not accepted funds for transportation controls and no other source of federal power exists to compel compliance, other cases of grant terminations for failure to implement transportation controls are far more problematic.

Consider, for example, the withholding of federal highway funds for failure to enforce transportation controls. When the new highways would generate a material increase in traffic in urban areas where federal ambient standards have not been met, highway funds could be conditioned on a state's implementation of transportation controls; otherwise federal grants would be contributing directly to the undermining of requirements set through a legitimate exercise of the commerce power. But (at least in a large state) a moratorium on all federal highway funds throughout the state or a region of the state 
might not be justified on such a rationale, because funding roadways in rural areas or other cities is not likely to contribute significantly to the pollution problem in a given urban area. This analysis indicates that there are likely to be substantial constitutional limitations on the exercise of the transportation grant sanctions provided in the 1977 Clean Air Act Amendments. 222

Nor is it easy to discern a justification for requiring enforcement of transportation controls as a condition on receipt of federal grants for other purposes, such as municipal waste treatment. A failure to enforce transportation controls could betoken lack of environmental zeal on the part of a municipality. That lack of zeal might arguably justify a denial of waste treatment grants on the ground that cities without a demonstrated commitment to environmental quality could not be expected to maintain and operate the resulting facilities. Or a "fiscal displacement" rationale for denial might be that federal grants to a state for one purpose free up available state funds for other activities, such as traffic control or highway construction, and that accordingly the federal government can impose conditions on such activities as the indirect beneficiaries of federal spending. ${ }^{233}$

222. Almost one-third of the $\$ 17.48$ bilion in state highway expenditures for fiscal 1975 had its source in conditional grants from the federal government. BuRE,L of THE Census, State Governiment Finances in 1975, Summaty Table 1, at 5 (1976). If eren a fraction of these grants could be related to automobilc pollution in areas where the federal ambient standards have not been met, the total amount of federal funds that could constitutionally be terminated for failure to enact transportation controls might be substantial in some areas. Howerer, the Department of Transportation would be understandably reluctant to terminate its program grants in order to assist EP.A.

Similar political factors would hinder enforcement of the provisions in $\$ 170(a)$ of the Clean Water Act as amended directing the Secretary of Transportation to deny approval of projects located in areas that fail to meet TCP requirements, and the provisions in $\$ 176(\mathrm{c})$ of the Act as amended directing federal officials generally to refuse funding, regulatory approval, or other support for activities which fail to meet applicable SIP requirements.

There are potential constitutional infirmities in the $\$ 176$ (a) requirement that the Secretary of Transportation and EPA deny "approval" of "projects" in areas not complying with TCP requirements. If the subsection refers solely to fecleral approval of federally funded programs, the question is raised whether such programs are sufficiently related to TCP objectives to support such a sanction. If "project" approval also includes regulatory approval of undertakings by private persons who are not responsible for automotive emissions or for the implementation of TCP measures, then the constitutional difficulties are cren more acute.

However, there appears to be no infirmity in $\$ 176(\mathrm{c})$ of the Act as amended which directs all fecteral officials to refuse funding, regulatory approval, or other support to activities that violate applicable SIP requirements. This provision does no more than prohibit federal assistance to or complicity in activities that transgless otherwise baliel recuirements of federal law.

223. For discussion of the "fiscal displacement" notion in the context of antidiscinination conditions on general resenue-sharing funds, sec Stolz, Revenue-Sharing-Netu American Rezolution or Trojan Horse?, 5s MiNN. I. REv. 1, 85-92 (1973). 
But such arguments are altogether too flimsy for the task. If accepted, they would permit federal control of almost any state or local governmental activity if those governments were receiving any federal funds, producing a virtually limitless power in a national government of limited powers. Moreover, such a broad reading of congressional power would afford Congress a way to exercise the spending power where it is not spending, by drafting grant conditions that reach areas in which the state has accepted no funds. Such an exercise is invalid by analogy to the limitation on the commerce porver that bars regulation of activities not involved in interstate commerce.

\section{NLC and the Spending Power}

The general analysis of the limitations on federal power to impose conditions on grants to states is fortified by the teachings of $N L C$. Conditioning federal funds upon state compliance with federal requirements in unrelated state programs that neither themselves receive federal funds nor are subject to direct federal control would pose grave threats to state self-determination of the sort condemned in $N L C$. If federal grants can be used in this circuitous fashion to induce adoption of unpopular programs, two outcomes are possible. First, the state may submit to the unpopular conditions and thus compromise its autonomy by permitting a federal circumvention of local mechanisms of political autonomy which is far more potent than would be the case if the only price for nonparticipation in the federal program were withdrawal of funds for that program alone. Alternatively, state officials can decide to forgo the federal funds (both those related and unrelated to the program which the state is being encouraged to adopt) and be forced either to curtail the overall scope of other state activities or raise taxes-the very results decried in NLC. Thus, $N L C$ suggests that conditions upon federal funds must be quite closely related to the state activities whose funding is subject to termination for noncompliance in order to limit the potential for infringements of state autonomy.224

There is a counterargument to the thesis that federal conditions enforced by termination of unrelated funds are suspect under $N L C$,

224. The analysis further suggests that grant conditions threatening state autonomy must meet a stricter test of relerance and necessity than in the case of private recipients. This parallels the requirement that spillover effects must be more substantial to justify coercive exercise of the commerce power against the states than against private persons. Sec p. 1229 \& note 129 supra. See also Note, supra note 50, at $1874-1878$ (reviewing recent Supreme Court decisions restricting the exercise of federal power where state autonomy was arguably threatened). 
whereas conditions enforced solely by termination of related funds are not. In either case, the state is faced with the alternatives of either complying with locally opposed federal.conditions or forgoing needed federal funds. The extent to which state self-determination is compromised in the two cases is arguably only one of degree to be assessed by a "balancing" test. But this counterargument ignores the strong federal interest in ensuring that federal funds raised by federal taxes are spent by the recipient in the service of federally defined objectives. This interest justifies termination of grants when recipients use the money for purposes inconsistent with the donor's objectives, but does not justify termination of unrelated grants. ${ }^{225}$

In summary, conditional grants do not offer an especially promising alternative for coercing state implementation of environmental policies in cases where $N L C$ restricts Congress's use of the commerce power for that purpose. Federal funding can be withdrawn from a state program that fails to comply with federal conditions relevant to the purpose of that program, if the conditions are "necessary and proper" to achieving the objectives of the funding and do not require drastic or unusual restructuring of state governmental machinery. However, there are serious political and bureaucratic obstacles to actually terminating federal grants or making the threat of termination credible. If actually put to the choice, state officials may often prefer to sacrifice the money rather than adopt locally unpopular environmental measures. The power of the federal government to promote state implementation of such measures by also withdrawing federal grants for other state activities is sharply circumscribed, both by the limited reach of Congress's general spending powers and by the constitutional barriers to federal intrusion on state autonomy recognized is $N L G .226$

225. Even related grant conditions may seriously undermine state self-determination because of state dependence on federal revenues and the fiscal "commons" problems. But if this line of argument were accepted, not only would the federal government be precluded from imposing conditions on federal grants to states, but it would be obligated to provide unconditional grants to the extent needed to make up state and local shortfalls in funding "integral" services. Judges are unlikely to find in $N L C$ an implication that revenue sharing to support certain broadly defined categorics of local services is constitutionally required. Bul cf. p. 1267 \& note 240 infra (discussing Michelman, supra note 146; Tribe, supra note 180 ).

226. This pessimistic conclusion is at odds with the optimism formerly expressed by the author concerning the utility of conditional grants as a tool for promoting statc implementation of federal environmental requirements. Sec Stewart, supra note 17, at 762. This changed view reflects more careful study of the issue; the author joins Justice Jackson's sentiment, rendered in similar circumstances, that "[t]he matter cloes not appear to me now as it appears to have appeared to me then." MicGrath $v$. Kristensen, 340 U.S. 162, 178 (1950) (Jackson, J., concurring). 
V. Conclusion: Judicial Limits on Congressional Power to Require State Execution of National Environmental Programs

\section{A. Federal Coercion of the States in Furtherance of National Moral Ideals}

The extent of Congress's power to mandate state implementation of national environmental policies must ultimately be defined by moral and political judgments based in part on an assessment of the practical threats to state autonomy that such a power would imply. The analysis in the preceding section indicates that the spending power cannot be relied upon, both for political and constitutional reasons, to secure state support for important but locally unpopular federal environmental policies. Accordingly, effective implementation of national environmental policies will depend to a material degree on Congress's authority to requisition the enforcement resources of state and local governments under the commerce power and under the power to resolve conflicts between states. These powers afford a far more secure base for federal control than the spending power. They do not depend upon the doubtful zeal of program officials in terminating grants for their own programs or taking other hostile measures against client state and local governments. ${ }^{227}$ Even if grant terminations are a real prospect, states might forgo federal monies in order to escape burdensome federal grant requirements. By contrast, states cannot so easily withdraw from activities that affect interstate commerce or other states; even were they able to do so, the activities in question would normally be taken over by private firms unquestionably subject to the commerce power.

But the efficacy of the coercive controls should by no means be overestimated. Congress remains an extraordinary barometer of intense local views. The federal EPA's programs to implement "indirect source" controls on new development and to limit parking in polluted central areas were emasculated by legislation after they attracted strong local hostility. ${ }^{228}$ The 1977 Clean Air Act Amendments have greatly eased the rigor of pre-existing pollution control requirements that had generated widespread opposition. ${ }^{229}$ Moreover, the

227. Sce Tomlinson \& Mashaw, supra note 199 , at $619-29$, discussing the reluctance of federal officials administering grant programs to institute litigation or take other steps provoking confrontation and exacerbation of controversy in order to enforce compliance with federal standards. To the extent that regulatory controls rather than grant conditions are utilized to constrain state behavior, their administration could more readily be entrusted to officials whose primary responsibility is enforcement.

228. See Stewart, note 17 supra, at 726-27.

229. Sce note 56 supra. 
effective ability of the federal judiciary to coerce state implementation of complex measures like transportation controls, which require the joint cooperation of numerous state and local bureaucracies and elected officials, is quite limited.230 Even the most "forward" court would pause long and hard at the prospect of a judicial receivership over all of the numerous state authorities and powers that would have to be marshaled to deal effectively with air and water pollution problems.

In NLC these political safeguards of federalism were relatively weak because the impact on local citizens of federal minimum wage requirements was diffuse, and enforcement through money judgments was readily available. ${ }^{231}$ But in the case of environmental controls, the efficacy of federalism safeguards is maximal. The burdens are highly visible or fall heavily on politically powerful interests (such as developers or central city retailers), and there are serious difficulties in framing sanctions which would ensure state implementation of federal requirements. These safeguards make it most unlikely that recognition of constitutional power in Congress to require state implementation of federal environmental requirements would pose a serious threat to state political autonomy. The prospect of federally imposed "pyramids of sacrifice" appears remote.

Juxtaposed to these political safeguards of federalism are the values whose realization depends upon a substantial degree of centralized direction. As we have seen, spillover effects among the states create the strongest justification for federal intervention to promote the federalist version of the categorical imperative and sustain the harmony of the Union. But in situations where pervasive and significant spillovers do not exist, it is necessary to consider the reserved question of Congress's power to compel state cooperation in the name of national moral ideals, since the analysis has demonstrated other rationales for infringing state autonomy to be weak.

The case for federal intervention to help realize moral ideals, such as protection of susceptible minorities or the opportunities of future generations, is only somewhat less strong than the spillover rationale. These ideals are valuable not merely for their own sake but also for the moral education fostered by their consideration. Environmental problems force us to face consequences of our immediate actions that

230. For discussion of the problems and opportunities faced by courts in framing remedies in the context of the emerging "public law" model of litigation, sec Chayes, The Role of the Judge in Public Law Litigation, 89 H.skv. L. REv. 1281 (1976).

231. See 29 U.S.C. \$ $216(\mathrm{~b})$ (Supp. V 1975). 
we would prefer to disregard because of their disturbing impact on fellow citizens, on future generations, and on the nature of our society. Such a confrontation is indispensable to the collective moral growth of our society. Given the logic of the "politics of sacrifice," this form of collective education is likely to be attenuated if the crucial decisions are excessively noncentralized.

It is not the case, however, that federal intrusions on local selfdetermination are justified so long as there is some moral purpose arguably served thereby. Three conditions should be met in order to justify use of the commerce power to coerce state implementation of national moral goals. First, the goals should be among those that could persuasively be regarded as basic in a reflective ideal of the good society. ${ }^{232}$ Second, the goals should be of a sort that are unlikely, because of structural defects, to be realized under a regime of noncentralized decisionmaking. Third, federal intervention should promise a substantial contribution to the realization of the goals. ${ }^{233}$ As in the case of interstate spillovers, courts should undertake a substantial inquiry in determining whether these threshold conditions have been met. There would seem to be only three types of environmental goals that could meet these criteria: the prevention of serious harm to human health; maintenance of diverse environments to stimulate individual and collective cultural development; and preservation of irreplaceable environmental assets for future generations. In these aspects of environmental protection, as in the elimination of racial and sexual discrimination ${ }^{234}$ and the effort to provide all with minimum levels of well-being, effective capacity for central direction in the definition and realization of moral ideals will often be indispensable. ${ }^{235}$

232. See Stewart, supra note 17 , at 750-51; see also Michelman, In Pursuit of Constitulional Welfare Rights: One View of Rawls' Theory of Justice, 121 U. PA. L. Rcv. 962 (1973).

233. The second and third criteria are analogous to the requirements for exercise of congressional power in the case of interstate spillovers. See pp. 1226-30 supra.

234. Cf. Fitzpatrick v. Bitzer, 427 U.S. 445 (1976) (Eleventh Amendment does not bar recovery of back pay from state employer as provided by federal statute passed under $\$ 5$ of the Fourteenth Amendment).

235. There is a potential affinity between the analysis suggested here and the efforts of Prolessors Michelman and Tribe to explain NLC as an effort to protect the states' capacity to fulfill obligations to their citizens, who have a right, grounded in the federal constitution, to certain basic local governmental services. See Michelman, supra note 146; Tribc, supra note 180.

As Professor Tribe develops at length, this reading of $N L C$ would justify federal intrusions on otherwise constitutionally protected local self-determination in instances where such intrusions served to advance the individual rights that assertediy underlie $N L C$. If the national moral goals advanced in this article were simply the obverse of the individual rights stressed by Professor Tribe, then our analyses would merge at this point. The justifications developed here for congressional intervention in a state's otherwise protected self-determination could then be restated as limited to (I) protecting 
This by no means implies an abandonment of federalism. Indeed, the lessons of environmental policy refute Harold Laski's conclusion that "the federal form . . . is unsuitable to the state of economic and social development that America has reached." ${ }^{336}$ The sobering fact is that environmental quality involves too many intricate, geographically variegated physical and institutional interrelations to be dictated from Washington. Substantial reliance on state and local action and judgment is inevitable. But the need for central stimulus and direction is equally clear. As the Supreme Court has remarked: "Our dual form of government has its perplexities, ... but it must be kept in mind that we are one people; and the powers ... conferred on the Nation are adapted to be exercised ... to promote the general welfare, material and moral." 237 These considerations justify a congressional power to mandate state controls on public pollution sources in order to achieve national moral ideals. They also reinforce the earlier conclusion that Congress has authority to require state control over both public and private pollution sources generating significant spillover effects. Given the various political safeguards of federalism, these powers would not unduly threaten state autonomy. ${ }^{238}$

(under Congress's power to revise or anticipate judge-made rules for resolving interstate disputes) the corresponding right under the categorical imperative principle of federalism to self-determination of other states impacted by spillorers; or (2) securing (under $\$ 5$ of the Fourtecnth Amendment or Congress's general Article I powers) the constitutionally protected interests of individual citizens in certain basic services.

While this conclusion would be more satisfying, aesthetically and theoretically, than my reliance on national moral goals as a second ground for federal intervention, I am unable to embrace it at this time. As explained below, see p. 1260 infra, I do not believe that the Michelman-Tribe analysis can be limited to the "traditional" governmental services mentioned in NLC; it must be extended to certain forms of government regulation of private conduct, such as pollution control and land use regulation. Inclusion in the protected sphere of collective goods like environmental quality makes it far more difficult to maintain the concept of individual rights to a minimum quantity of certain basic goods and services, for it is often highly impractical to provide everyone with minimum levels of certain goods, such as unspoiled environments, that may nonetheless be essential to a society that pretends to excellence or justice to its successors. See Stewart, supra note 17, at 750-58; see also C. FrIEd, RIGHT AND Wrong ch. 6 (forthcoming 1978) (developing other difficulties in the notion of individual rights to collective goods). These difficulties pose serious problems for the Michelman-Tribe analyses, and infect $N L C$ itself because it affords protected status to certain local services, such as fire, police protection and parks, that are collective goods at least in part. I remain hopeful that it may be possible to resolve the conflict between traditional notions of individual entitlement and the growing recognition of the special problems presented by governmental provision of collective goods. See Stewart, supra note 17; Stewart, Paradoxes of Liberly, Integrity and Fraternity: The Colleclive Nature of Environmental Quality and Judicial Review of Administrative Action, ENvir. L. (forthcoming 1977). But a great deal more work must be done to unravel those difficulties.

236. Quoted in Freund, Federalism in America, 10 Perspectives USA 5, 6 (1955).

237. Hoke v. United States, 227 U.S. 308, 322 (1913).

238. For an initial statement of an alternative approach to the constitutional issues presented, sec Note, supra note 50 . Beyond insistence on a clear statement from Congress 


\section{Problems of Federalism in National Environmental Policy}

\section{B. The Implications of NLC}

Two final issues remain. First, is $N L C$ sound in granting constitutional protection only to traditional local governmental services, or should the protected sphere include other, equally important local functions, such as regulation of private conduct? The second, and previously reserved, issue is whether such federalism limitations, however defined, should be judicially enforced.

Professors Frank Michelman and Laurence Tribe have each sought to explain and (if $I$ read them aright) justify $N L C$ as (a) recognizing a special role for local government in providing certain traditional free public services and (b) logically implying correlative rights on the part of local citizens with respect to such services. ${ }^{239}$ While welcoming these creative analyses, I do not see how such rights can be limited to delivery of traditional local services such as fire and police protection, sanitation, or education. Some of the most important services rendered by the modern state to its citizens consist of regulating private behavior to correct for market imperfections created by externalities, large scale economies, imperfect information, and the like. The justifications suggested by $N L C$ and Professors Michelman and Tribe for recognizing a special constitutional place for traditional state and local government services extends as well to at least some of the regulatory activities of the administrative state, including, in particular, the maintenance of environmental quality and prevention of environmental degradation through controls on land use and pollution. The values of local self-determination are surely as important in matters such as zoning and pollution control as they are in the delivery of protective services, education, sanitation, maintenance of parks and recreation facilities, and other functions deemed "integral" by NLG.2屯0 If, as Professors Michelman and Tribe

of an intention to invade state autonomy (a requirement which this author shares), the Note would require federal judges to determine whether congressionally mandated intrusions could be avoided by less intrusive measures that would substantially accomplish the federal goal. See id. at 1888-189l. While the "less intrusive alternative" notion may be a useful starting point for analysis, it suffers from two important limitations in the context of environmental policy. First, for reasons developed in the introductory section of this Article, it may be impossible to achieve many federal environmental goals without mandating a substantial measure of state implementation. Sccond (as admitted in the Note, id. at 1890-91), the doctrine would, in order to have significant application, require the judges to weigh in an ad hoc, fact-intensive fashion the competing claims of state autonomy and national supremacy. For reasons developed carlier in this article, see p. 1236 supra, the author believes that such an ad hoc "balancing" approach should be avoided to the extent possible.

239. See Michelman, supra note 146; Tribe, supra note 180.

240. See Village of Belle Terre v. Boraas, 416 U.S. 1 (1974) (sustaining use of the local zoning power to exclude certain classes of potential residents in order to maintain 
argue, $N L C$ must be justified as preserving the states' capacity to meet basic individual needs, it is difficult to distinguish police and fire protection (recognized as "integral" by NLC) from state control of lethal pollutants emitted by private sources.

The obvious problem with recognizing state autonomy in areas of environmental regulation is that it appears flatly inconsistent with the well-established authority of Congress under the commerce power to regulate local activity and preempt state control. ${ }^{241}$ This seeming inconsistency between $N L C$ 's implications and settled precedent must lead to one of three conclusions. ${ }^{242}$ The first is that Justice Brennan is correct in asserting that NLC is simply at odds with the commerce clause cases sustaining Congress's power to displace state regulation of private activity and that $N L C$ is unsound. ${ }^{243} \mathrm{~A}$ second conclusion is that the inconsistency between $N L C$ and the regulatory decisions demonstrates that the latter have been superseded and must be revised in light of $N L C .^{244}$ A third possible conclusion is that $N L C$ 's

a community's existing character). Full enforcement of the requirement in the Clean Air Act that national ambient air quality standards be maintained in the face of con. tinued economic growth and derelopment would severely restrict local zoning and land use decisions. See Note, EPA Regulation of "Indirect Sources": A Skeptical View, 12 HaRv. J. Legis. 111, 132-53 (1974).

241. See, e.g., Burbank v. Lockheed Air Terminal, Inc., 411 U.S. 624 (1973) (preemption of state and local standards for aircraft noise); Northern States Power Co. $\checkmark$. Minnesota, 477 F.2d 1143 (8th Cir. 1971), aff'd, 405 U.S. 1035 (1972) (preemption of state regulation of radioactive emissions by nuclear power plants). Such precmption, however, is comparatively rare in current federal statutes. See, e.g., Clean Air Act $\$ 116$, 42 U.S.C. $\$ 1857$ d-1 (Supp. V 1975) (authorizing states, with certain exceptions, to impose more rigorous standards and controls than federal law requires).

242. A fourth potential conclusion is that the federalism limitations on national power should be confined to certain frec local services that the states have traditionally provided, and not extended to other forms of local activity such as regulation or provision of "proprietary" services such as railroad transport, see United States v. California, 297 U.S. 175 (1936), or commercial products, $c f$. New York $v$. United States, 326 U.S. 572 (1946) (Tenth Amendment does not immunize state sales of mineral waters from federal taxation). For reasons sketched in the text, there appears to be no reasoned basis for such a distinction. However, an arbitrary restriction on federalism protections might be judged a practical necessity in order to carre out an area of local self-determinttion without unduly threatening national power or requiring the judges to engage in an extended ad hoc "balancing" effort to reconcile competing claims of national and local power.

243. See 426 U.S. at $867-68,875$ (Bremnan, J., disscnting).

244. $N L C$ offers no justification for excluding state regulatory activities from the protected sphere of "integral" or "traditional" state and local functions. Certainly the protection of individuals from unsafe or unhealthy conditions through regulation of private conduct has been a "traditional" state and local function; and if sanitation and fire and police protection are classified as "integral," it is difficult to understand why such regulation should not be similarly classified. Federal override or premption of such regulation represents an "exercise of congressional authority dirccted . . to the States as States," $i d$. at 845 , and constitutes a far more direct "congressionally imposcd displacement of state decisions," $i d$. at 849 , than the measures condemned in $N L C$. 
implications are not, on closer analysis, inconsistent with the decisions sustaining Congress's sweeping power to regulate private activity. In many of those cases, the state whose capacity to control certain private conduct was effectively displaced was not the party challenging federal measures. ${ }^{245}$ In addition, even where state claims of autonomy were explicitly subordinated to federal power, the decisions might be explained along the lines of the analysis developed in Part III of this article. For example, cases of national preemption of state regulation might be justified in terms of legitimately dominant national interests in preventing interstate spillovers ${ }^{\mathbf{2 4 6}}$ or advancing moral goals basic to individual or societal integrity. ${ }^{247}$ In short, the logical implications of $N L G$ need not be inconsistent with existing doctrine. The analysis developed here can justify broad congressional power while recognizing strong claims of protection for local services beyond "traditional" functions mentioned in NLC.

\section{The Justiciability of Federalism Limitations on Congressional Power}

Finally, it remains to consider whether federalism limitations on national powers, however these limitations may be defined, should be judicially enforceable. The issues presented are not of a type wholly beyond judicial competence; they are at least analogous to the questions which federal judges have regularly confronted in litigation challenging state measures as contrary to the commerce clause or to assertedly preemptive federal legislation. ${ }^{248}$ However, those cases involved setting aside the statutes of a subordinate governmental unit as required by the supremacy clause. Invalidation of federal statutes as intrusions on state autonomy, on the other hand, involves the courts in a confrontation with Congress and the President over wheth-

245. See, e.g., Heart of Atlanta Motel v. United States, 379 U.S. 241 (1964) (hotel owner unsuccessfully challenges Civil Rights Act of 1964); United States v. Darby, 312 U.S. 100 (1941) (lumber manufacturer unsuccessfully challenges 1938 Fair Labor Standards Act); cf. Steward Machinc Co. v. Davis, 301 U.S. 548, 585, 589-90 (1937) (rejecting contentions that federal tax credit conditioned on employer contributions to state unemployment compensation scheme meeting federal specifications violated Tenth Amendment and noting that only employer, and not state, was advancing this argument).

246. For example, federal preemption of local regulation of airport noise could be sustained on the ground that local noise regulation might seriously disrupt or burden interstate air travel. See City of Burbank v. Lockheed Air Terminal, Inc., 411 U.S. 624 (1973).

247. The nondegradation requirement in the Clean Air Act, limiting development in states with high air quality, is justified by moral values associated with environmental diversity. See Stewart, supra note 17, at 750-58.

248. See generally Freund, Umpiring the Federal System, 54 CoLuM. L. REv. 561 (1951). 
er the judicial or political branches of the national government are supreme in matters of social and economic policy. While purporting to vindicate "structural" principles implicit in the Constitution, the effect (and, perhaps, the perceived purpose) of the judges' decisions would, as Justice Brennan points out in his $N L C$ dissent, be to stultify social and economic policies conceived by the political branches. ${ }^{249}$

These dangers are reinforced on consideration of $N L C$ 's implications for the commerce clause decisions sustaining federal regulatory power over private activity and the displacement or preemption of state regulation and state taxation. Such decisions reflect judicial reluctance to impose federalism limitations on congressional action precisely because of the confrontation between court and legislature that such limitations would involve, and the serious difficulties the courts would face in developing a reasoned and widely acceptable justification for imposing such restraints. But our previous discussion indicates that these decisions must be qualified or at least reexamined in light of $N L C$. Thus NLC appears to establish precedent for extensive federal court inquiry into the constitutionality of previously unquestioned congressional acts, and invites the very confrontation that the Justices have for the past 40 years been careful to eschew.

The hazards in judicial enforcement of federalism limitations on national power would be ameliorated if the Michelman and Tribe analyses of NLC were accepted. If $N L C$ were interpreted as based upon a doctrine of citizens' rights to certain forms of local services, courts could then assume a characteristic role in reviewing the constitutionality of congressional legislation to protect individual rights. Under such circumstances, the risks of judicial intervention might be worth running. But even if the Michelman-Tribe analyses were accepted, it does not follow that states should have standing to enforce federalism limitations designed to secure rights of individual citizens. Limiting standing to the citizens themselves would clarify the underlying issues and make explicit the basis for judicial review. ${ }^{250}$

249. See 426 U.S. at 875-78 (Brennan, J., dissenting).

The hazards in judges using federalism principles to invalidate federal statutes are thus analogous to those involved in striking down enactments as unconstitutional delegations of legislative power. See Schechter Poultry Corp. v. United States, 295 U.S. 495 (1935); Panama Refining Co. v. Ryan, 293 U.S. 388 (1935).

250. On the analyses suggested by Professors Michelman and Tribe, the municipalities in $N L C$ were presumably afforded standing in order to vindicate the interests (indecd, the rights) of their citizens to receive certain local governmental services. This form of surrogate standing raises dangers of conflict of interest and confusion in framing the merits. See Stewart, supra note 71, at 1730-34.

Similar dangers are present even if standing is afforded on a jus tertii theory based on the states' duty to vindicate the rights of their citizens to basic services and decisions. $C f$. 
Finally, there is the pragmatic question of the need for the courts to impose federalism constraints on legislation, in view of the alternative political safeguards of federalism. For reasons discussed earlier, these safeguards are quite powerful in the realm of environmental policy. While weaker in the NLC context, they still had considerable strength. In this student's view, the occasion for judicial enforcement of federalism limitations on otherwise valid exercises of congressional power has not been presented. Far more sweeping incursions on state autonomy were held nonjusticiable in Georgia $v$. Stanton..$^{201}$

It does not necessarily follow that a case might not be presented justifying judicial invalidation of congressional statutes on generalized federalism grounds. ${ }^{252}$ Moreover, if it could be shown that federalism limitations were a central element in evolving conceptions of individual rights to basic amenities, then such limitations might well be enforced by courts where necessary to secure such rights. Occasional judicial review will also ensure that Congress remains aware of its responsibilities to give weight to state and local autonomy in framing legislation. For these reasons, a flat holding that federalism limitations are nonjusticiable is undesirable. The Court should acknowledge extensive congressional discretion to determine whether national interests in preventing spillovers or advancing moral goals justify overriding state autonomy, while maintaining a reserve of judicial power

Note, Slanding to Assert Constitutional Jus Tertii, 88 HARv. L. REv. 423 (1974) (discussing, and generally favorable to, jus tertii standing). There is no assurance, for example, that freeing municipalities from the fiscal burdens of the Fair Labor Standards Act will translate into increased levels of free, essential services for all. Given the availability of legal services representation, it might be preferable to insist that the citizens asserting rights to local governmental services maintain the litigation against federal requirements that assertedly burden the fulfillment of those rights. While such plaintiffs might have difficulty in establishing a sufficiently clear link between federal requirements and impairment of local services to them to meet the limitations on standing erected in Simon v. Eastern Ky. Welfare Rights Org., 426 U.S. 26, 40-41 (1976), these limitations are particularly appropriate where a constitutional challenge to congressional regulation is made. And requiring the citizen-recipients to institute suit would confront the court with the problem of defining the asserted right to receive essential governmental services. It is better to face these problems squarely than to obscure them through surrogate standing for states and municipalities. Cf. Steward Machine Co. v. Davis, 301 U.S. 548 (1937) (rejecting claims by a federal taxpayer that a tax impaired state sovereignty). In particular, under the Michelman-Tribe reading of $N L C$ it would seem difficult to establish the sort of demonstrable nexus between the claims of plaintiff states and municipalities and effective vindication of citizen rights that is appropriate in judicial review of congressional legislation on constitutional grounds.

251. 73 U.S. (6 Wall.) 50 (1868).

252. See Coyle v. Smith, 221 U.S. 559 (1911) (invalidating federal statute fixing location of newly admitted state's capital as undue interference with state sovereignty). 
to deal with extreme cases. ${ }^{253}$ If this strategy is adopted, the constitutional issues will be primarily addressed and resolved by the Congress. When Congress does so, the analysis in Part III of this article should lead it to reject wholesale claims that federal coercion of state officials to implement national environmental policies is unconstitutional.

253. See Helvering v. Davis, 301 U.S. 619, 640 (1937); Steward Machine Co. v. Davis, 301 U.S. 548 (1937). In these cases the Court accorded great discretion to Congress in determining whether certain spending and tax measures would advance the general welfare, while reserving judicial power to invalidate patent abuses of that discretion. The course suggested is similar to that pursued by reviewing courts with respect to administrative action assertedly "committed to agency discretion" under the Administrative Procedure Act, 5 U.S.C. $\S 701$ (a)(2) (1970), and therefore not subject to review. Courts will decline to go deeply into the merits of decisions that are prima facie within the range of choice accorded the agency by statute in cases where judicial review would be particularly burdensome or would have little to contribute through application of reasoned principles, while reserving power to analyze closely and invalidate measures plainly unlawful. See, e.g., Hahn v. Gottlieb, 430 F.2d 1243, 1251 (1st Cir. 1970). 